\title{
In Respect of People Living in a Permanent Vegetative State - and Allowing Them to Die
}

Lois Shepherd

Follow this and additional works at: https://scholarlycommons.law.case.edu/healthmatrix

Part of the Health Law and Policy Commons

\section{Recommended Citation}

Lois Shepherd, In Respect of People Living in a Permanent Vegetative State - and Allowing Them to Die, 16 Health Matrix 631 (2006) Available at: https://scholarlycommons.law.case.edu/healthmatrix/vol16/iss2/9

This Article is brought to you for free and open access by the Student Journals at Case Western Reserve University School of Law Scholarly Commons. It has been accepted for inclusion in Health Matrix: The Journal of Law-Medicine by an authorized administrator of Case Western Reserve University School of Law Scholarly Commons. 


\title{
IN RESPECT OF PEOPLE LIVING IN A PERMANENT VEGETATIVE STATE- AND ALLOWING THEM TO DIE
}

\author{
Lois Shepherd ${ }^{\dagger}$
}

\section{PROPOSAL}

1. Recognize the person in a permanent vegetative state as a living person with rights to self-determination, bodily integrity, and medical privacy.

2. Recognize that people in a permanent vegetative state are not like other people who are severely disabled in that they have absolutely no interest in continued living.

3. Recognize that for people in a permanent vegetative state, the current legal presumption in favor of indefinite tube feeding generally does not allow their preferences or their interests to prevail; change that presumption only for people in a permanent vegetative state to favor discontinuing tube feeding.

4. Require judicial or quasi-judicial review of continued tube feeding after a specified period of time following the onset of the person's vegetative state, such as two years, well beyond the period when diagnosis of permanent vegetative state can be determined to a highdegree of medical certainty.

\section{INTRODUCTION}

When Terri Schiavo's feeding tube ${ }^{1}$ was removed in March 2005, some protesters went on hunger strike. ${ }^{2}$ Others placed red tape over

${ }^{\dagger}$ D'Alemberte Professor of Law, Florida State University College of Law. I wish to thank Florida State University for its continued research support.

"By "feeding tube," I refer to the means by which Terri Schiavo was provided artificial nutrition and hydration, through a percutaneous endoscopic gastromony (PEG tube), and other forms of artificial feeding. See generally David Orentlicher \& Christopher M. Callahan, Feeding Tubes, Slippery Slopes, and Physician-Assisted Suicide, 25 J. LEGAL MED. 389, 390-92 (2004) (providing descriptions of various methods of artificial feeding); David Casarett et al., Appropriate Use of Artificial Nutrition and Hydration-Fundamental Principles and Recommendations, 353 N. ENG. J. MED. 2607 (2005) (providing a general discussion of current ethical guidelines and clinical practices regarding feeding tubes). 
their mouths with the word "life" written on it. ${ }^{3}$ Children were arrested trying to bring water to Terri in the hospice. ${ }^{4}$ The passions of demonstrators favoring government action to reinsert her feeding tube were publicly, visibly high.

What about those of us who thought she should be allowed to die? Where was our passion? We had no slogan as simple and powerful as "life." Championing the "rule of law" seemed uncaring and hollow; and rules can be changed. Yet slowly and quietly, as Terri's case traveled from the Florida legislature to the U.S. Congress, from state to federal court, from the trial to the appellate level, and back and forth and back again, people who favored the removal of her feeding tube began to speak about Terri being "used" and "exploited," about her being treated as a "pawn," a "thing," rather than a person. We began to feel safe in expressing our own passion-in defense of Terri's privacy, her humanity, and her rights.

But this championing of Terri's humanity applies beyond her case. The argument should be recognized as applicable to most people in a permanent vegetative state and further, it should be recognized as requiring a fundamental shift in the way we regard such people. The terms of the debate over the legal treatment of people in a permanent vegetative state require reordering.

Continued tube feeding of people in a permanent vegetative state, unless they have indicated their preference for such, cannot be justified as an action taken in their interest. Rather, such feeding is done in the interests of others, whether they be politicians or loved ones, or certain members of the medical profession who believe feeding is morally required, or society in general. The result is an instrumental use of the person in a permanent vegetative state and even, at times, as we saw in the recent Terri Schiavo controversy, an exploitation. Photographs and videotapes of Terri's slack mouth and vacant expression were broadcast repeatedly on television and could be viewed at any time, by anyone, over the internet. ${ }^{5}$ These images looked nothing like

2 See Daniel J. Hemer, Schiavo Case Spurs Hunger Strike, HARV. CRIMSON, Mar. 23, 2005, available at http://www.thecrimson.com/article.aspx?ref=506693; Chris Tisch et al., Judge Greer Parts Ways with His Church on Pastor's Advice, ST. Petersburg Times OnLine, Mar. 22, 2005, available at http://www.sptimes.com/ 2005/03/22/Tampabay/Judge_Greer_parts_way.shtml.

${ }^{3}$ Kenneth Lovett \& Deborah Orin, Anguished Prayers \& Angry Chants as Rival Protestors Square Off, N.Y. PosT, Mar. 25, 2005, at 4.

${ }^{4}$ See David Sommer, Charges Are Still Pending Against Schiavo Protestors, TAMPA TRIB., Apr. 13, 2005, Metro, at 6 (describing arrest of six children).

5 See Terri Schindler Schiavo Found, http://www.terrisfight.org (last visited Mar. 3, 2006). On the website were several photographs and also videoclips of Terri Schiavo in the condition in which she existed for many years, which the Florida cir- 
the attractive woman she used to be. While they were offered by her parents in their fight to keep her alive, the broadcast of these images demonstrated quite tragically that Terri was used as an instrument for others' purposes, rather than treated as a person deserving of respect and privacy. The U.S. Congress' attempt in March 2005 to issue a subpoena for Terri's "testimony" before a congressional committee 6 and the sensational offers by private individuals of millions of dollars to Terri's husband to relinquish guardianship to her parents ${ }^{7}$ were of the same ilk. Could it really have been supposed that her public display in a congressional carnival would have counted as testimony? Could her life or death been auctioned to the highest bidder?

These actions were justified by those who took them as being for Terri's benefit. But there was no benefit to her in continued living. She could not feel, see, hear, taste, smell, perceive, think, or experience life in any way at all, nor had she been able to for fourteen years, nor would she ever again. ${ }^{8}$ These actions were not for Terri's benefit. Nor was she kept alive by tube feeding because she had made it clear, prior to entering a state of permanent unconsciousness, that she would want to continue living in such condition-perhaps to hold out hope of a cure, however slim, or because she believed a good afterlife required it, or for any other personally held hopes, beliefs, or principles. Instead, a court determined that there was clear and convincing evidence that she would not have wanted to continue living in this condition. ${ }^{9}$ Our society was being neither benevolent, nor respecting her

cuit court determined, upon the evidence submitted by numerous doctors, was a permanent vegetative state. $I d$. There are also photographs of what Terri looked like before the heart attack that led to her vegetative condition. Id. Videoclips of Terri are no longer available on this website, but are available at the time of this printing on http://www.blogsforterri.com/archives/video_of_terri/ (last visited May 9, 2006). For an analysis of the media use of the videos (and also to view two of the videos), see Diane Waldman, Timely Triage: Schiavo Videos-Context and Reception, Jumpcut, http://www.ejumpcut.org/currentissue/SchiavoWaldman/index.html (last visited May $9,2006)$.

6 Phil Long et al., Terri Schiavo Case: Judge Rejects Congress' Subpoena, Miam Herald, Mar. 19, 2005, at 1A. Pinellas Circuit Judge George Greer, who presided over the Schiavo case from its inception, did not allow the Congressional action to delay the removal of Terri's feeding tube. Id.

${ }^{7}$ William R. Levesque, \$1-Million Offered to End Husband's Role, ST. Petersburg TimES, Mar. 11, 2005, at 1A (reporting statement by Michael Schiavo's attorney that Michael had turned down at least three offers (of $\$ 700,000, \$ 1,000,000$ and $\$ 10,000,000$ ) to remove himself from the guardianship role in Terri's case).

${ }^{8}$ See infra Part II for a description of the permanent vegetative state and a discussion of Terri Schiavo's diagnosis.

${ }^{9}$ In re Guardianship of Schiavo (Schiavo I), 780 So. 2d 176 (Fla. Dist. Ct. App. 2001) (affirming trial court's determination that clear and convincing evidence existed that Terri Schiavo would have wanted to discontinue tube feeding). 
right to self-determination, when we continued to tube feed her. Instead, she was kept alive for others' benefit and on the basis of others' hopes, beliefs, or principles.

Even before the Florida governor, ${ }^{10}$ Florida legislature, ${ }^{11}$ and U.S. Congress $^{12}$ stepped into Terri's case to extend her life, she was living for many years for someone else-namely her parents, Robert and Mary Schindler. Through various legal challenges, they delayed the removal of Terri's feeding tube from February 2000, when the first court order permitting removal of the tube was issued, to March $2005 .^{13}$ Emotional attachments such as these are understandable and require our sympathetic and sensitive recognition. But at the same

${ }^{10}$ The Florida Governor became involved in the case in a number of ways. First, he pushed for the state legislature to pass "Terri's Law" in October 2003, which permitted the Governor to order reinsertion of her feeding tube. See S.B. 12-E, H.B. 35-E (Fla. 2003). The Governor then became involved over the following year with defending his action under Terri's Law, which Terri's husband, Michael Schiavo, challenged as unconstitutional. That law was held unconstitutional by the Florida Supreme Court in September of 2004. Bush v. Schiavo, 885 So. 2d 321 (Fla. 2004) (holding that Terri's Law violated separation of powers principles). For a discussion of the separation of powers principles involved in the case, see Barbara A. Noah, Politicizing the End of Life: Lessons from the Schiavo Controversy, 59 U. MIAMI L. REV. 107, 116-20 (2004) (arguing that Terri's Law violated numerous Florida constitutional provisions); O Carter Snead, Dynamic Complementarity: Terri's Law and Separation of Powers Principles in the End-of-Life Context, 57 FLA. L. REV. 53 (2005) (arguing that the law did not violate separation of powers). Supporters of Terri's parents sought the Governor's help again in March 2005 when a third removal of her feeding tube was imminent and after it had been withdrawn. The Governor sought to establish the right of Florida's Department of Children and Family Services to place Terri in its custody on the grounds that she was being abused. Judge Greer, who presided over Terri's case in the circuit court of Florida, blocked the Govemor's action. See Carol Marbin Miller, Plan to Seize Schiavo Fizzles, Miami Herald, Mar. 26,2005 , at $1 \mathrm{~A}$.

"See S.B. 12-E, H.B. 35-E (Terri's Law).

12 On March 21, 2005, Congress passed a law that stated that the United States District Court for the Middle District of Florida shall have jurisdiction to hear a suit regarding alleged violations of Terri Schiavo's constitutional or federal rights regarding the "withdrawal of food, fluids, or medical treatment necessary to sustain her life." The law also provided that the district court shall engage in "de novo" review of such claims and disregard state court proceedings that had taken place. Relief of the Parents of Theresa Marie Schiavo, Pub. L. No. 109-3, 119 Stat. 15 (2005). The district court denied the Schindlers' motion for a temporary restraining order to require reinsertion of Terri's feeding tube under the jurisdiction granted by Congress. See Schiavo ex rel. Schindler v. Schiavo, 358 F. Supp 2d 1161 (M.D. Fla. 2005), aff'd, 403 F.3d 1261 (11th Cir. 2005).

${ }^{13}$ For a detailed chronology of the controversy from the time of Terri Schiavo's collapse in 1990 to December 2003, see JAY WOLFSON, A REPORT TO

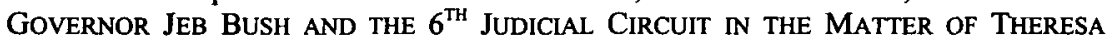
MARIE Schiavo (2003) (Wolfson was appointed the guardian ad litem to Terri Schiavo in October 2003). 
time, we must acknowledge that they do not provide any benefit that is experienced by the person in the permanent vegetative state, who, again, cannot experience anything.

Individuals such as Terri Schiavo, who are permanently unconscious, should be treated as the living persons they are. In respecting them, we should honor their prior capacity for self-determination and follow their wishes regarding continued medical treatment (including artificial sustenance), if they can be determined. We should also respect their rights to medical privacy by not allowing them to become objects of public display. We should respect their bodily integrity by providing proper hygiene and giving care to their appearance. Most importantly, we should adhere to our fundamental obligation in respect of persons, an obligation that is prior to and includes the more particular duties to respect self-determination, privacy, and bodily integrity, and that is the obligation to avoid allowing the instrumental use of such individuals.

The instrumental use of permanently unconscious individuals is a real and fundamental risk of any legal system for end-of-life decisionmaking that is based upon a blanket presumption in favor of life. In such a system, the interests of others in continuing such a person's continued life, be they political, financial, medical, or familial interests, are too often allowed to trump.

In this article, I argue for a change in state laws that govern the treatment of people in a permanent vegetative state. The Schiavo controversy provides the medical and legal framework for probing the weaknesses of existing law and considering possible reforms. My proposal treats people in a permanent vegetative state as persons, with rights to self-determination, bodily integrity, and medical privacy. But it requires understanding that these people are in a special category; they are not like the terminally ill or those who have already died (the "brain dead"). They are also not like fetuses, or embryos, or people on death row-despite comparisons made to Terri Schiavo by right-tolife and other groups. ${ }^{14}$ Most importantly, they are not like other

${ }^{14}$ See, e.g., Scarborough Country: Furnell Chatman, Pat Buchanan (MSNBC television broadcast May 3, 2005) (linking Schiavo and abortion issues as involving issues of preserving innocent human life); Josh Harkinson, Westward Whoa! Stem Cell Restrictions Could Send Texas Medical Center Researchers Fleeing to California, Hous. PRESS, May 19, 2005 (explaining that because states cannot constitutionally prohibit abortion, "pro-life groups focus on related hot-button topics" like Terri Schiavo's case and embryonic stem cell research). See generally JoN EISENBERG, USING TERRI: THE RELIGIOUS RIGHT'S CONSPIRACY TO TAKE AWAY OUR RigHTS (2005) (describing the role of pro-life groups in the quest to keep Terri Schiavo's feeding tube in place). 
people who are severely disabled and because they are not, individualized, personalized assessments of the interests of the patient in continued feeding can be replaced with a presumption that tube feeding should be discontinued. Under my proposal, the surrogate's role in such cases is reduced to bringing forward evidence, if it exists, that the patient would have wanted continued tube feeding. Such evidence can rebut the presumption against discontinuing tube feeding. Review of decisions to continue feeding is required at regular intervals by courts or accredited ethics committees to ensure that such decisions are in conformity with patients' wishes.

In Part I of the article, I describe the characteristics of people in a permanent vegetative state. In Part II, I explain that people in a permanent vegetative state have no interest in continued living and are therefore distinguishable from other people who are severely disabled, requiring the permanently vegetative unique legal consideration. Part III explains how the current law fails people in a permanent vegetative state by allowing them to be perpetually fed in service to the interests of others. The kinds of interests that might improperly influence the decision to continue tube feeding against the patient's interests and preferences are discussed in Part IV. Part V explains how changing the presumption in favor of discontinuing tube feeding better ensures the effectuation of patient preferences and regard for the personhood of people in a permanent vegetative state. Part VI addresses possible objections to my proposal.

\section{PEOPLE IN A PERMANENT VEGETATIVE STATE}

The term "persistent vegetative state" was adopted in 1972 by Drs. Jennett and Plum to describe patients who had, after trauma to the brain, entered a continuing state of unconsciousness marked by periods of wakefulness. ${ }^{15}$ The term has been widely adopted by those both inside and outside the medical community. ${ }^{16}$ While originally intended to signal a continuing, or persistent, condition, from which recovery may or may not occur, the term has come to be associated with a diagnosis of a permanent, rather than merely long-lasting con-

15 Bryan Jennett \& Fred Plum, Persistent Vegetative State after Brain Damage: A Syndrome in Search of a Name, 1972 LANCET 734, 736 (1972).

${ }^{16}$ BRyan JenNetT, ThE Vegetative STATE: Medical FaCts, ETHICAL AND Legal Dilemmas 3 (2002). See also Am. Neurological Ass'n Comm. on Ethical Affairs, Persistent Vegetative State: Report of the American Neurological Association Committee on Ethical Affairs, 33 AnNALs NEURoLogy 386, 386 (1993); MultiSociety Task Force on PVS, Medical Aspects of the Persistent Vegetative State (First of Two Parts), 330 N. ENG. J. MED. 1499, 1499-1500 (1994) [hereinafter Task Force Report, Part I]. 
dition. ${ }^{17}$ Recently, experts have suggested distinguishing the condition of patients who have recently entered the state as "vegetative" and, when the condition is considered irreversible on the basis of medical criteria, to use the term "permanently vegetative." 18

While there are no clear numbers of how many people live in a permanent vegetative state in this country, estimates put the number at between 10,000 and 25,000 adults and 6,000 to 10,000 children. ${ }^{19}$ There are four major characteristics of individuals in a permanent vegetative state that are relevant in evaluating the appropriate legal
$17 \mathrm{Id}$. at 5.
18 JENNETT, supra note 16, at 4-5.

In this article, I use the term "permanent vegetative state" to refer to the condition at issue, which is the variant of vegetativeness that is considered irreversible. At times, the term "persistent vegetative state" is also used because state statutes, court opinions, and commentators have used and continue to use this term, but unless otherwise noted, the reference to "persistent" should not be understood as connoting something other than a permanent condition. The term "permanently unconscious" could also have been used, but that term might be understood as including individuals in a coma from brain damage who do not emerge from that condition before death. Id. at 2. After their death we can say that from the time of entering the coma they were permanently unconscious, but that is different from diagnosing them as having entered into a state of permanent unconsciousness with its attendant ethical and legal issues.

A number of commentators have protested the use of the term "vegetative" as demeaning because of its suggestion that the patient is something less than a person, a mere "vegetable." See, e.g., Raphael Cohen-Almagor, Some Observations on Post-Coma Unawareness Patients and on Other Forms of Unconscious Patients: Policy Proposals, 16 MED. \& L. 451, 461 (1997) ("the term 'vegetative' dehumanizes the patients, suggesting that we speak of some form of sub-human life"); Adam J. Hildebrand, Masked Intentions: The Masquerade of Killing Thoughts Used to Justify Dehydrating and Starving People in a "Persistent Vegetative State" and People with Other Profound Neurological Impairments, 16 IsSUES L. \& MED 143, 148-49 (2000) (arguing that the term is "an insult to the inherent dignity of the human person"). While I am sympathetic to this argument, especially because my project involves highlighting and appreciating the personhood of people in a permanent vegetative state, nevertheless the terminology has become so widespread, with no alternative yet achieving any significant use, that to use a different term may cause confusion. The need for clear use of terms is imperative in this area so that any policy adopted is applied only to those for whom it was intended. The condition of individuals who have some degree of consciousness, even if they respond in a very limited and inconsistent way, should not be confused with patients in a permanent vegetative state. The term as adopted as Jennett and Plum was intended to distinguish between such patients: "The former should be regarded as very severely disabled and not as in a lesser degree of the vegetative state. Recently the terms minimally responsive state or minimally conscious state have emerged to describe those patients who have regained very limited conscious responses." JENNETT, supra note 16, at 2 (citations omitted).

${ }^{19}$ Quality Standards Subcomm., Am. Acad. of Neurology, Practice Parameters: Assessment and Management of Patients in the Persistent Vegetative State (Summary Statement), 45 NEUROLOGY 1015, 1015 (1994). 
rules for making decisions regarding their treatment: (1) such individuals are living persons; (2) they absolutely lack consciousness; (3) their condition is permanent; (4) they may live for many years, even decades, with artificially provided nutrition and hydration. ${ }^{20}$ Each of these characteristics and their relevance to questions of the law's response to such individuals is discussed in turn.

\section{A. People in a Permanent Vegetative State Are Living Persons}

People in a permanent vegetative state are not dead under our current medical and legal understanding of death. ${ }^{21}$ Despite a number of newspaper articles that described Terri Schiavo as a "brain dead" woman, ${ }^{22}$ she was not dead during the controversy that surrounded her because her brain stem, which controls autonomic responses such as respiratory and cardiac activity, was still functioning. ${ }^{23}$ The law in all fifty states and the District of Columbia requires a complete lack of brain function, including function within the brain stem, before brain death has occurred. ${ }^{24}$

Arguments have been made for a number of decades, however, by Robert M. Veatch and others, that such persons should be considered dead because they have no higher brain function and only a functioning brain stem. ${ }^{25}$ Under such theories, consciousness or the possibility of future consciousness would be required for a person to be considered living and thus the possessor of rights and interests that must be respected. An obvious benefit of this proposed redefining of death

20 JENNETT, supra note 16, at 66. See infra Part I.D.

21 Marcia Angell, After Quinlan: The Dilemma of the Persistent Vegetative State, 330 NEW ENG. J. MED. 1524, 1524-25 (1994).

22 See, e.g., Maya Bell, Florida Agency Won't Investigate Alleged Abuse of Brain-Dead Woman, DulUTH NEWS-TRIB. (Minn.), Mar. 11, 2005; Florida Justices Hear Right-to-Die Case; Court to Review New State Law Keeping Brain-Dead Woman Alive, SAN JOSE MERCURY NEWS, Aug. 31, 2004, at 7A.

${ }^{23}$ Angell, supra note 21, at 1524-25.

24 JANET L. DOLGIN \& LoIS L. SHEPHERD, BIOETHICS AND THE LAW 834 (2005). An individual whose death is determined on the basis of a lack of brain function cannot sustain cardiopulmonary function without mechanical aid. They may be attached to such mechanical aids prior to the determination of brain death or even after such determination in order to permit continued oxygenation of their organs and tissues for transplant opportunities. Once they are withdrawn from the machines that sustain their cardiopulmonary functions, their lungs no longer draw breath, their hearts no longer beat, and they satisfy the traditional criteria for determining deaththe irreversible cessation of cardiopulmonary function. Angell, supra note 21, at 1524-25.

${ }^{25}$ See Robert M. Veatch, Brain Death and Slippery Slopes, 3 J. CLINICAL Ethics 181 (1992); Robert M. Veatch, The Dead Donor Rule: True by Definition, 3 AM. J. BIOETHICS 10, 10-11 (2003) [hereinafter Dead Donor Rule]. 
would be the availability of the bodies of such individuals for organ harvesting.

The argument to redefine death to include people in a permanent vegetative state or others who are permanently unconscious has generally fallen on deaf ears and for good reason. The biological fact is that the patient is breathing on her own, without any ventilator support, and therefore fits just about everybody's idea of what constitutes "living."26 As Marcia Angell wrote in 1994, they just don't "look dead." 27 Moreover, removing the vital organs of such people would clearly cause them to pass into another state - the state we universally understand as death, where respiratory and cardiac function are irreversibly lost. Clearly, efforts to change the legal definition of death to encompass individuals who have no higher brain function is less about defining biological life and death and more about saying that we have good reasons to exclude certain individuals from the community that matters. The reality, however, is that for most people, individuals in a permanent vegetative state, individuals like Terri Schiavo, do matter. There may have been wide disagreement about what should be done for Terri Schiavo, but she clearly counted as a person while living in a permanent vegetative state.

Treating the person in a permanent vegetative state as a person requires that we protect her from being treated merely as a means to others' ends. In this article, I assume the truth of this fundamental principle of the proper treatment of persons rather than debate its merit. The principle has both ancient (Aristotle) ${ }^{28}$ and more modern (Kant) ${ }^{29}$ philosophical exponents and has been a foundational assumption of American jurisprudence relating to medical decision-making and treatment of the human body. ${ }^{30}$ In fact, the reason a number of

${ }^{26}$ See Howard Trachtman, Death Be Not Political, 3 AM. J. BioETHICs 31, 31-32 (2003).

27 Angell, supra note 21, at 1525 .

${ }^{28}$ See Loren E. Lomasky, Person, Concept of, in ENCYCLOPEDIA OF ETHICS 1293, 1294 (Lawrence C. Becker \& Charlotte B. Becker eds., 2d ed. 2001).

${ }^{29}$ See John D. Arras et al., Moral Reasoning in the Medical Context, in ETHICAL IsSUES IN MODERN MEDICINE 1, 14-17 (John D. Arras \& Bonnie Steinbock eds., 5th ed. 1999).

${ }^{30}$ See, e.g., Roe v. Wade, 410 U.S. 113 (1973) (the Supreme Court determined first the status of the fetus as a non-person before determining that a pregnant woman has a right to an abortion). For a more recent example, see the discussion by members of the President's Council on Bioethics regarding human cloning, which presents the question of the status of the embryo as one whose outcome determined members' views of the propriety of creating, using, and destroying cloned embryos for medical research purposes. PRESIDENT's CounCIL on BIOETHICS, HuMAN CLONING AND HUMAN DIGNITY: AN ETHICAL INQUIRY (2002), available at http://www. bioethics.gov/reports/cloningreport/index.html. 
scholars who advocate taking the organs of people in a permanent vegetative state argue that such individuals are dead is to work around the prohibition against using the person solely as an instrument for others. ${ }^{31}$ Instead of adopting wholesale utilitarianism, a moral philosophy that would permit outright the use of some individuals for the greater good, such scholars generally acknowledge and retain a certain adherence to the principle that those who count as "persons" within the moral community are "ends in themselves" and that respecting them qua persons means disallowing their instrumental use.

Under my argument, and somewhat paradoxically, allowing the permanently vegetative patient to die treats her more like a person, respects her more as a person, than continuing to feed her and sustain her life.

\section{B. People in a Permanent Vegetative State Lack any Consciousness}

While people in a permanent vegetative state are not dead, but living people, they have no higher brain function, which means that their senses are absent-all of them. ${ }^{32}$ According to a 1994 report of the Multi-Society Task Force on PVS, comprised of representatives of U.S. neurological and pediatric associations, ${ }^{33}$ people in a vegetative state have a "complete unawareness of the self and the environment. ${ }^{\text {"34 }}$ While the website that Terri's parents maintained included a videotape that seemed to show Terri's eyes tracking a balloon and Terri smiling in response to her mother's presence, ${ }^{35}$ those videotapes were misleading. And every court who reviewed the complete (rather than sound bite) evidence agreed. ${ }^{36}$ They showed moments taken from

${ }^{31}$ See Dead Donor Rule, supra note 25, at 10-11 (advocating an expansion of the definition of death to include patients in a permanent vegetative state over abandoning the dead donor rule as a strategy for allowing organs to be taken from such patients).

32 For a description of the characteristics of people in a permanent vegetative state, see JENNETT, supra note 16, at 7-32; Task Force Report, Part I, supra note 16, at 1499. See generally Quality Standards Subcomm, supra note 19, at 1016.

${ }^{33}$ Representatives of the following societies formed the Multi-Society Task Force on PVS: the American Academy of Neurology, Child Neurology Society, American Association of Neurological Surgeons, American Neurological Association, and the American Academy of Pediatrics. The Task Force also consulted many experts in medical and allied health fields, ethics, and law. The executive committee of each participating society approved the Task Force Report. See Task Force Report, Part I, supra note 16, at 1499-1500.

${ }_{34}$ Id. at 1499.

35 See Terri Schindler Schiavo Found., supra note 5.

${ }^{36}$ See In re Guardianship of Schiavo (Schiavo IV), 851 So. 2d 182, 186 (Fla. Dist. Ct. App. 2003) (explaining that the guardianship (or trial) court had reviewed the videotapes, as had the appellate court: "We have repeatedly examined the video- 
hours and hours of videotaping in which Terri's eyes wandered without purpose, without seeing, and in which her mouth showed all sorts of expression, although they were not expressions relating to anything going on around her ${ }^{37}$ Such "activity" is consistent with the diagnosis of a permanent vegetative condition. ${ }^{38}$ Such patients are not asleep, with their eyes closed, as many people may have supposed before seeing Terri Schiavo on television or the internet. That is the condition of people who are in a coma. A coma is a temporary state of unconsciousness that a person may fall into after a head injury or similar trauma ${ }^{39}$ In fact, Terri entered a coma after the cardiac arrest that caused her current condition. ${ }^{40}$ During that period she would have appeared to have been asleep. ${ }^{41}$ But all patients who enter a coma either then move into a state of some improvement (some degree of consciousness), or move deeper into the stable and persistent condition of permanent vegetative state. ${ }^{42}$ The latter individuals exhibit some movements that may make them appear to be conscious, which is disconcerting to those around them. They have sleep and wake cycles, and during their wake cycles, their eyes are open. ${ }^{43}$ They may have startle reflexes, where the body reacts to a sudden stimulation. ${ }^{44}$

tapes, not merely watching short segments but carefully observing the tapes in their entirety. ... We have concluded that, if we were called upon to review the guardianship court's decision de novo, we would still affirm it.").

${ }^{37}$ Stephen Nohlgren, Schiavo Tapes: Snippets, Then Not Much, ST. Petersburg Times, Nov. 10, 2003, at $1 \mathrm{~A}$.

${ }^{38}$ According to Bryan Jennett, "[w]hat characterizes the vegetative state is the combination of periods of wakeful eye opening without any evidence of a working mind either receiving or projecting information, a dissociation between arousal and awareness." JENNETT, supra note 16, at 8-9.

${ }^{39}$ For comparisons between persistent vegetative state and coma, see Task Force Report, Part I, supra note 16, at 1501-02

${ }^{40}$ See WOLFSON, supra note 13, at 7.

${ }^{41}$ See Task Force Report, Part I, supra note 16, at 1501-02.

42 See Task Force Report, Part I, supra note 16, at 1499.

${ }^{43}$ Id. at 1500.

44 As Jennett writes,

[t]he limbs are usually spastic and they may move in a nonpurposeful way and there may be groping movements. A grasp reflect may be set off by contact with bedclothes, the nasogastric tube or the hand of an observer and these may be misinterpreted as indicating voluntary movements or meaningful responses, especially by relatives seeking evidence for recovery. However, careful observation reveals no consistent movements that are voluntary or learned, or a response to command or mimicry.

JENNETT, supra note 16, at 14-15. In addition,

[m]ost patients show some response to painful stimuli. A stimulated limb may withdraw or there may be a generalized movement of all four limbs, sometimes accompanied by facial grimacing and perhaps a groan. There may also be a rise in respiratory and pulse rates and in blood pressure. It is 
For family members who love the patient, who seek any sign that the person they love is still able to perceive them, it can be very difficult to accept that these activities do not signal understanding or perception. The belief they sometimes hold that their loved one is somehow "locked in" is, unfortunately, false. ${ }^{45}$ In fact, over time, the lack of function in the higher brain of the patient in a permanent vegetative state reveals itself in an atrophy of brain tissue. A scan of Terri Schiavo's brain showed that by 1996, six years after she had entered a permanent vegetative state, "much of her cerebral cortex [was] simply gone and [had] been replaced by cerebral spinal fluid."46 After her death, an autopsy confirmed this conclusion. ${ }^{47}$

The Terri Schiavo controversy brought to public attention another medical condition, the minimally conscious state, which Terri's parents and others eventually claimed she was in. The critical difference between a minimally conscious state and a permanent vegetative state is that the former condition involves some level of cognitive function, while there is no evidence of cognition associated with the permanent

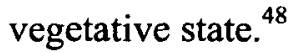

generally held that these responses are all at reflex level and do not indicate Id. at 15 . that pain is being experienced on a conscious level.

45 With "locked-in" syndrome, the patient is paralyzed, but has not lost sensation or cognition. Such patients generally have limited eye movement and can blink to communicate in a yes/no code, revealing their cognition. Id. at 20-21. As Jennett writes, "[s]killed neurologists seldom have difficulty in distinguishing this condition from the vegetative state, and, in any event, the history of causation is usually quite different." Id. at 21.

${ }^{46}$ In re Guardianship of Schiavo (Schiavo I), 780 So. 2d 176, 177 (Fla. Dist. Ct. App. 2001).

${ }^{47}$ See Jon Thogmartin, Report of Autopsy of Theresa Schiavo, Case 5050429 (June 13, 2005), available at http://www.miami.edu/ethics/schiavo/061505autopsy.pdf; C. Christopher Hook \& Paul S. Mueller, The Terri Schiavo Saga: The Making of a Tragedy and Lessons Learned, 80 MAYO CLINIC ProC. 1449 (2005) (summarizing autopsy results, including fact that Terri's brain weighed less than half the expected weight of a person her age).

48 The criteria for diagnosing the minimally conscious state, as recently developed by a group of experts, are as follows:

Evidence of limited but clearly discernible self or environmental awareness on a reproducible or sustained basis, by one or more of these behaviours:

1. Simple command following

2. Gestural or verbal 'yes/no' responses (regardless of accuracy)

3. Intelligible verbalization

4. Purposeful behaviour including movements or affective behaviours in contingent relation to relevant stimuli; examples include:

(a) appropriate smiling or crying to relevant visual or linguistic stimuli 
That Terri Schiavo was in a permanent vegetative state was confirmed by several highly qualified board-certified neurologists. ${ }^{49}$ In 2000 , when the trial court ordered the first removal of Terri's feeding tube, it did so after hearing evidence regarding her medical condition and her wishes with respect to discontinuation of treatment. ${ }^{50}$ Another lengthy hearing was held in 2002 at the instigation of the Schindlers, at which "each side had ample opportunity to present detailed medical evidence, all of which was subjected to thorough crossexamination." ${ }^{\text {"1 }}$ The appellate court, reviewing the evidence and affirming the trial judge's determination that Terri Schiavo remained in a permanent vegetative state, stated that "[i]t is likely that no guardianship court has ever received as much high-quality medical evidence in such a proceeding." 52 In this hearing, five doctors were asked to evaluate Terri's condition-two chosen by Michael Schiavo, two by the Schindlers, and one by the court. ${ }^{53}$ The court found convincing the testimony given by the doctors chosen by Michael Schiavo and by the court, which attested to Terri Schiavo's permanent vegetative condition. ${ }^{54}$ The testimony offered by the two doctors chosen by the Schindlers regarding Terri's likelihood of improvement was not actually very different from the testimony offered by the other doctors, and to the extent it did differ, it was not persuasive. ${ }^{55}$

(b) response to linguistic content of questions by vocalisation or gesture

(c) reaching for objects in appropriate direction and location

(d) touching or holding objects by accommodating to size and shape

(e) sustained visual fixation or tracking as response to moving stimuli.

JENNETT, supra note 16, at 24 (citing Joseph T. Giacino et al., The Minimally Conscious State: Definition and Diagnostic Criteria, 58 NEUROLOGY 349, 351 (2002) (outlining the criteria this group of experts propose as a standard for the health profession)).

49 This includes the two doctors who originally certified her condition, which provided support for Michael Schiavo's original petition to have Terri's wishes regarding nutrition and hydration be determined. Three doctors testified that Terri was in a permanent vegetative state in the hearing described below.

50 The medical evidence is described in In re Guardianship of Schiavo (Schiavo II), 792 So. 2d 551, 554, 560 (Fla. Dist. Ct. App. 2001).

${ }^{51}$ In re Guardianship of Schiavo (Schiavo IV), 851 So. 2d 182, 185 (Fla. Dist. Ct. App. 2003) (affirming the trial court's decision, following this hearing, that the Schindlers had not established that new treatments offered the possibility of improvement in Terri's condition such that she would elect to undergo such treatments).

${ }^{52}$ Id.

53 Id. at 184.

54 Id. at 185 .

${ }^{55}$ Id. at 184-85. "Although the physicians are not in complete agreement 
The accuracy of the diagnosis is very important under existing Florida law because, like the "end of life" statutes in some other states, Florida's statute makes clear that permanent vegetative state is one of the conditions in which life-sustaining treatment, including artificially provided nutrition and hydration, can be withdrawn. ${ }^{56}$ The treatment of a person in a coma would not be covered by Florida's statute, nor would someone who is severely disabled, but stable-in other words, someone who can still experience life in some manner, however meager that experience may be. ${ }^{57}$

The accuracy of the diagnosis is also important under the reforms that I propose. My argument for changing some of the substantive and procedural guidelines for withdrawing tube feeding from individuals in a permanent vegetative state depends upon the lack of any present or future perception of the patient-in other words, permanent unconsciousness. This proposal, like current law, does not cover individuals who are severely disabled but still experience some feelings or thoughts. Such individuals merit separate and different consideration because proposals to discontinue feeding in those instances requires figuring out how to weight or value those experiences. The law in many states, including Florida, makes a sharp distinction between individuals who have no experiences (i.e., those in a permanent vegetative state) and individuals who have minimal experiences, by includ-

concerning the extent of Mrs. Schiavo's brain damage, they all agree that the brain scans show extensive permanent damage to her brain. The only debate between the doctors is whether she has a small amount of isolated living tissue in her cerebral cortex or whether she has no living tissue in her cerebral cortex." Id. at 184. The Guardian Ad Litem's report states, "Of the two physicians testifying for the Schindlers, only one was a neurologist, the other was a radiologist/hyperbaric physician. The testimony of the Schindler's [sic] physicians was substantially anecdotal, and was reasonably deemed to be not clear and convincing." WOLFSON, supra note 13 , at 16 .

${ }^{56}$ Permanent vegetative state is one of three such conditions-the others being a terminal condition and an end-stage condition (such as advanced Alzheimer's disease). FLA. STAT. ANN. § 765.304(2)(b) (West 2005) (requiring one of these conditions be present before proceeding with a living will); $\$ 765.305$ (limiting the decision to withdraw life-prolonging treatment by patient-appointed surrogate to these three conditions); $\S 765.401$ (similar limitation for surrogate designated through statutory priority list). The Florida statute uses the term "persistent vegetative state" rather than permanent vegetative state, but defines it as "a permanent and irreversible condition of unconsciousness in which there is: (a) The absence of voluntary action or cognitive behavior of any kind. (b) An inability to communicate or interact purposefully with the environment." $\$ 765.101(12)$.

57 Certain kinds of treatment might be foregone in such instances, and in fact, patients might have a constitutional or common law right to have such treatment withdrawn, but the Florida statute does not place its imprimatur of approval on such decisions with its grant of immunity to those who engage in such decisions. 
ing the former in "end of life" statutes, but excluding the latter. ${ }^{58}$ There are some good reasons to maintain those distinctions, as will become clear. ${ }^{59}$

Scientific inquiry consistently brings new discoveries, and if in the future we were to learn either that (1) people in what we now call a permanent vegetative state do actually have some degree of meaningful perception or (2) people in a permanent vegetative state have a reasonable probability of recovering some degree of meaningful perception, then my proposal would need reevaluation. It is based upon the permanent lack of consciousness.

\section{The Lack of Consciousness of People in a Permanent Vegetative State Is Permanent}

To call the prognosis of the patient in a permanent vegetative state "dim" would be an overstatement. The very definition of the condition requires that it be permanent, irreversible. The diagnosis is not properly entered until sufficient time has passed to preclude any reasonable probability of recovery. ${ }^{60}$ In 1994, the Multi-Society Task Force determined that a judgment that a vegetative state was permanent could be made twelve months after a traumatic injury in adults and children, and after three months when the cause of the condition was nontraumatic. ${ }^{61}$ Recovery after this time is extremely rare. ${ }^{62}$

Under my proposal, the presumption that tube feeding should be discontinued would not be applicable until a prognosis of permanence could be made. Moreover, the part of the proposal that requires judicial or quasi-judicial review of continued tube feeding (the part of the proposal that prevents surrogates from indefinitely ordering tube feeding without evidence of patient preferences for it) would not apply until a certain specified time after the vegetative condition has been entered, such as two years, which is well beyond the guidelines that physicians follow in making a determination of permanence.

${ }^{58}$ FLA. STAT. ANN. $\S 765.305$ (2)(b) (West 2005) (requiring surrogate to be satisfied that the patient is in an end-stage condition, persistent vegetative state, or that the patient's condition is terminal); FLA. STAT. ANN. § 765.401(3) (West 2005) (requiring statutorily designated surrogates, or proxies, to meet the standards of \$ 765.305).

59 See supra Part II.

${ }^{60}$ Multi-Society Task Force on PVS, Medical Aspects of the Persistent Vegetative State (Second of Two Parts), 330 N. ENG. J. MED. 1572, 1575 (1994) [hereinafter Task Force Report, Part II].

${ }^{62}$ Id. 
It is true that there have been reports of late recoveries. In reviewing thirty media reports of alleged late and unexpected recoveries from either a prolonged coma or a vegetative state, the Multi-Society Task Force discovered that in fifteen of those cases, recovery had in fact occurred prior to the recommended period for determining permanence. ${ }^{63}$ Only two of the remaining cases appeared (on the basis of the limited information available) to be definitely vegetative; each of these recovered five months after a nontraumatic injury. Nine of the cases were definitely not vegetative, and the other four only possibly vegetative. $^{64}$

The Mutli-Society Task Force also considered medically verified late recoveries, but found similar problems with the data. ${ }^{65}$ Again, some of the alleged late recoveries appear to have been late discoveries of recoveries that had actually taken place before the recommended guidelines for determining permanence. ${ }^{66}$ The Multi-Society Task Force recognized, however, that a rare late recovery is possible, explaining that "like all clinical diagnoses in medicine, [diagnosis of a permanent vegetative state] is based on probabilities, not absolutes." ${ }^{, 67}$ But the data were sufficient, in the Multi-Society Task Force's view, to make distinctions between vegetative states that could only be considered persistent and those which could be considered irreversible, and thus permanent:

A patient in a persistent vegetative state becomes permanently vegetative when the diagnosis of irreversibility can be established with a high degree of clinical certainty-that is, when the chance that the patient will regain consciousness is exceedingly small. We believe there are sufficient data on the prognosis for neurologic recovery to allow us to distinguish between persistent and permanent vegetative states. These data, in conjunction with other relevant factors in an individual patient, can be used by a physician to determine when the persistent vegetative state becomes permanent-that is, when a physician can tell the patient's family or surrogate with a high degree of medical certainty that there is no further hope

${ }^{63}$ Jennett summarizes this work of the Task Force. See JENNETT, supra note 16 , at 63 .

${ }^{64} I d$. at 63 (explaining how the Task Force used a sample of thirty media reports to explore single-case examples which defied their official recommended 'periods of expected recovery).

${ }^{65}$ Id. at 63-64.

${ }_{66}$ Id. at 64 . See also Task Force Report, Part II, supra note 60, at 1575.

${ }^{67}$ Task Force Report, Part I, supra note 16, at 1501. 
for recovery of consciousness or that, if consciousness were recovered, the patient would be left severely disabled. ${ }^{68}$

As with nearly all decisions regarding medical diagnosis and treatment, 100 percent certainty is not possible. But we should not allow an exceedingly small possibility of recovery from a condition of permanent vegetativeness, ${ }^{69}$ or the possibility of mistaken diagnosis, ${ }^{70}$ to permit continued tube feeding for the thousands of people who are properly diagnosed as being in a permanent vegetative state on the basis of clear and conservative clinical guidelines. ${ }^{71}$

\section{People in a Permanent Vegetative State May Live for Many Years}

While the prognosis for someone in a permanent vegetative state ever recovering any ability to experience life is so extremely poor that it is, for all intents and purposes, zero, the prognosis for continued

${ }^{68}$ Id. In those rare instances where a late recovery may have occurred ("late" meaning past the recommended guidelines for a declaration of permanence, which the Task Force placed at three months for nontraumatic injury; twelve months for traumatic injury), "recovery" was almost always to a condition of very severe disability, such as a "minimally conscious state or slightly better." JENNETT, supra note 16, at 64.

${ }^{69}$ If this rare occurrence took place, it would be merely into a condition of very severe disability, such as a minimally conscious state.

${ }^{70}$ The Task Force Report acknowledges that we cannot be absolutely certain there is no consciousness; that judgment requires inferring "the presence or absence of conscious experience in another person." Task Force Report, Part I, supra note 16, at 1501 . "[I]t is theoretically possible that a patient who appears to be in a persistent vegetative state retains awareness but shows no evidence of it. In the practice of neurology, this possibility is sufficiently rare that it does not interfere with a clinical diagnosis carefully established by experts." Id.

${ }^{71}$ As an example of the conservative nature of the guidelines established by the Multi-Society Task Force on PVS, its report cautions against diagnosing a vegetative state when there is any degree of sustained visual pursuit although it may not evidence consciousness:

Sustained visual pursuit is lacking in most patients in a vegetative state.

They do not fixate on a visual target, track moving objects with their eyes, or withdraw from threatening gestures. . . . However, patients in a vegetative state often have inconsistent primitive auditory or visual orienting reflexes, characterized by a turning of the head and eyes toward peripheral sounds or movements. In rare cases, patients who have no other evidence of consciousness over a period of months to years have some degree of briefly sustained visual pursuit or fixation, which is believed to be mediated through brain-stem structures. Nevertheless, one should be extremely cautious in making a diagnosis of the vegetative state when there is any degree of sustained visual pursuit, consistent and reproducible visual fixation, or response to threatening gestures.

Task Force Report, Part I, supra note 16, at 1500-01. 
existence is not as bad, at least for someone who has survived in a permanent vegetative state for over one year. If given good nursing care, the person in a permanent vegetative state can live for thirty or more years. ${ }^{72}$ Part of this nursing care consists of artificially provided nutrition and hydration, usually through a percutaneous endoscopic gastrostomy (a PEG tube), which is surgically inserted directly into the stomach. ${ }^{73}$ Individuals in a permanent vegetative state cannot cooperate with spoon or straw feeding. It may be technically possible to feed some such patients by spoon or straw, but there will be no conscious response from the individual ${ }^{74}$-and such efforts will really amount to forcing food down the throat of the individual, an intrusion of bodily integrity that may even appear more invasive than the insertion of a feeding tube.

\section{PEOPLE IN A PERMANENT VEGETATIVE STATE HAVE NO INTEREST IN CONTINUED LIVING}

My argument for a presumption against perpetually tube feeding people in a permanent vegetative state rests on the fact that continued existence serves no present or future interests of the person. Continuing tube feeding in the absence of evidence of the patient's wishes is thus an act of improper instrumental use of the person. If life is not being continued for the benefit of the patient, then it is being continued for the benefit of others.

The argument that people in a permanent vegetative state have no interest in continued living is not new. A number of commentators have recognized this lack of interest because such a person cannot and never will experience life in any way. ${ }^{75}$ In other words, they will

72 JENNETT, supra note 16 , at 66 . There have been reported cases of individuals living thirty-seven and forty-one years. Id. The Task Force reported that survival beyond ten years was unusual, but its data may have placed estimates at long-term survival too low. Id. Jennett describes how the publication of the Task Force Report provoked a number of letters protesting these numbers, some of which pointed out that they may have been based on deaths that resulted from decisions to limit treatment. Id. at 67. A similar response followed a British documentary on permanent vegetative state in 1994, in which of 458 members of the public who called in stating that they were related to family members in a vegetative state, seventy-eight reported that their relative had been in a vegetative state for more than ten years. Id. at 66-67.

${ }^{73} I d$. at 88 . A nasogastric tube (which is inserted through the nose) is also sometimes used, especially in the early period of vegetativeness. Id.

74 See id. at 18.

75 See, e.g., Allen E. Buchanan \& DAN W. Brock, DeCiding For OtHERs: THE ETHICS OF SurRogate DeCISION MAKING 126-129 (1989); and Rebecca Dresser, Life, Death, and Incompetent Patients: Conceptual Infirmities and Hidden Values in the Law, 28 ARIZ. L. REV., 373 (1986). 
never perceive what is going on around them or what is happening to them. They also unfortunately completely lack an "inner life" as well-in terms of memories or musings or dreams.

Continued feeding in such instances is not required for the purpose of benefiting the patient because continued life does not benefit the patient in any way that can be experienced. Interests of this sort, which can be experienced by the patient, are frequently called "experiential interests." $" 76$

This complete lack of experiential interests is what makes the condition of the permanent vegetative state unique and calls for appropriately unique ethical and legal consideration. Such consideration means first that people in a permanent vegetative state can be, should be, and must be treated as a unique class with respect to how we think of the benefit to them in tube feeding because they all have the same complete lack of experiential interests. Second, the complete lack of interest in continued living means that people in a permanent vegetative state are not like other severely disabled individuals who, because of their varying capacities to experience life, cannot be treated as a class and do have specific, individual interests in continuing to live. As a result, the class of persons who are permanently vegetative must be treated differently from other severely disabled individuals.

For example, we do not need to ask for people in a permanent vegetative state, how much are they suffering? Would a few more days of life be a valued experience to the patient? Will the feeding tubes disturb the patient? There is no such difficult individualized assessment for the vegetative patient-feeding by tube is relatively simple and effective in prolonging the life of the individual in a permanent vegetative state. Removal of the feeding tube will undoubtedly cause death within a period of weeks. The analysis is always the same-simple feeding mechanisms continue life; removal causes death. The feeding tubes are not experienced by people in a permanent vegetative state in any way, nor is the life that they gain by such feeding tubes.

While we should recognize that any individualized assessment of the experiential interests of the permanently vegetative patient is unnecessary, that does not mean that we should discard an individualized assessment of what they would want done in this situation. The law governing end-of-life decision-making does and probably should continue to respect the wishes of the patient; to the extent they can be

${ }^{76}$ See supra Part II.A. 
discerned. ${ }^{77}$ The reforms that I propose maintain deference to the individual wishes of the patient.

Sometimes, in the more theoretical of discussions about patients' interests at the end of life, a distinction is made between experiential interests, which people in a permanent vegetative state clearly do not have, and other interests that a patient may have. ${ }^{78}$ Arguments have been made that these other sorts of interests, which people in a permanent vegetative state may possess, should be factored into a decision whether or not to continue life-prolonging treatment. ${ }^{79}$ For example, in his book Life's Dominion, Ronald Dworkin distinguishes between a person's "experiential" interests and "critical" interests. While Dworkin agrees that people in a permanent vegetative state have no "experiential" interests, he argues that they may nevertheless have "critical" interests-interests that their lives as a whole be successful according to certain critical judgments that they as individuals at one time possessed. ${ }^{81}$ For example, a person may believe that to have a successful life includes being remembered as an independent, alert, dignified person. Forgoing life-prolonging treatments in a state of dependency may be in keeping with that earlier judgment. Another person may believe that a successful life would entail staying alive with "the virtue of defiance in the face of inevitable death." ${ }^{.82}$ The critical interests of the latter person may be respected by continuing, rather than forgoing, life-prolonging treatment.

Philosophers Allen Buchanan and Dan Brock have identified a similar way of looking at the interests of people in a permanent vegetative state that are not limited to their experiential interests. They say that some people, prior to entering a vegetative state, may have "had certain future-oriented interests which will be satisfied or thwarted depending on what happens to him or her after becoming permanently unconscious." ${ }^{83}$ Thus, according to Buchanan and Brock, a person may have an interest in being sustained in a permanent vegetative state for some time because of religious values. ${ }^{84}$

\footnotetext{
77 See generally infra Part III.

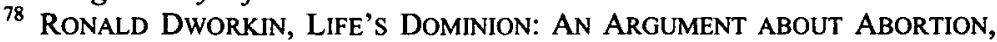
EUTHANASIA, AND INDIVIDUAL FREEDOM 201-213 (1993).

${ }^{79}$ Id.

$80 \mathrm{Id}$.

81 Id.

$82 \mathrm{Id}$. at 213.

${ }^{83}$ BuCHANAN \& BROCK, supra note 75, at 129.

${ }^{84}$ Id.
} 
Under my view, non-experiential interests of the "critical" or "future-oriented" sort are important, but are better understood as patient preferences rather than interests per se. I do not, therefore, treat them as true present or future interests in continued living that would be a part of a best interests' analysis. Instead, evidence about the views the patient may have had about life in a permanent vegetative state is the sort of evidence that should be brought to bear on a surrogate's understanding of the patient's preferences and the surrogate's decision about whether continued feeding is in accordance with or contrary to the wishes of the patient.

But I would caution against--and my proposal does not at all require-making any generalizations about what people's critical or future-oriented interests may be. There may be a temptation to consider interests in dignity, for example, or interests in being remembered in a pre-disability state as so common and universally possessed that we should consider existence in a permanent vegetative state itself as a burden in respect to these interests. In other words, some would argue that there are burdens to the continued life of a person in a permanent vegetative state, burdens of humiliation, dependence, and indignity. ${ }^{85}$ The patient has an interest, under this argument, in avoiding these burdens by dying.

Admittedly, there is something compelling to this line of argument, and (again) if we are trying to figure out what the person would want if she could now tell us, these might be some of the things she would say. But adding this "burdens to living" component to the analysis is not necessary. It is not necessary because the absence of benefit alone is enough to discontinue life-prolonging treatment for people in a permanent vegetative state unless there is sufficient evidence of their contrary wishes. It is enough because if tube feeding is not done to benefit the people who are fed, then it is done to benefit other people, thus constituting an unacceptable instrumental use of the person.

Understanding people in a permanent vegetative state as being "burdened by life" is an approach which could apply just as well to those who are severely disabled but conscious and opens the door to a set of objections that should not be faced in treatment questions about the permanently vegetative. It is important to understand the sharp differences between the conditions of the permanently vegetative and the severely disabled with some consciousness. Two very difficult issues are embedded in end-of-life decision-making about the severely

${ }^{85}$ See Norman L. Cantor, The Permanently Unconscious Patient, NonFeeding and Euthanasia, 15 AM. J. L. \& MED. 381, 414-15 (1989). 
disabled that support a more cautious approach to discontinuing treatment for such individuals than for patients in a permanent vegetative state. ${ }^{86}$ First, a decision to terminate life-sustaining treatment for a severely disabled individual may involve, or may be perceived as involving, unacceptable judgments about the quality and value of the person's life vis-à-vis her abilities. Concerns about a life without dignity also suggest an inhospitability toward dependency, with potentially negative consequences toward those who are dependent. ${ }^{87}$

Second, if a decision to terminate treatment is made on the basis of the individual's living will ${ }^{88}$ or other pre-disability statements about the undesirability of continued life in a certain condition, then the individual's pre-disability autonomy might be given preferential weight over the individual's post-disability interests, and it is not clear that this should be so. With the terminally ill, this trumping of "critical interests" over "experiential interests" has become fairly accepted, as long as present interests in comfort are maintained. ${ }^{89}$ In other words, life-sustaining treatment might be removed from a patient with only a few weeks to live on the basis of his formerly expressed wishes, even though he still retains some level of consciousness and might be said to benefit from continued life. But we do not generally allow withdrawal of life-sustaining treatment from the severely disabled who are not permanently unconscious or not terminally ill, unless the treatment itself causes severe suffering. ${ }^{90}$ There is more at

${ }^{86}$ The law of most states does not provide for the discontinuation of lifesustaining treatment for severely disabled patients who are neither terminally ill nor in a persistent vegetative state. Such patients may still have a constitutional or common law right to discontinuation of treatment, but no statutory immunity is granted for those involved in a decision to terminate treatment. In some ways, this lack of immunity suggests that discontinuation of life-sustaining treatment for such individuals would not be appropriate absent extraordinary circumstances.

87 See generally Lois Shepherd, Face to Face: A Call for Radical Responsibility in Place of Compassion, 77 ST. JOHN'S L. REV. 445 (2003); and Lois Shepherd, Dignity and Autonomy after Washington v. Glucksberg: An Essay about Abortion, Death, and Crime, 7 CORNELl J. L. \& PuB. POL'Y 431 (1997-1998).

${ }^{88}$ A "living will" generally denotes a written document that provides instructions regarding the continuation of life-sustaining treatment in certain conditions, such as a terminal illness or permanent vegetative state.

89 See infra Part III. For example, Florida law excludes from the definition of "life-prolonging procedures" that can be withheld or withdrawn "the administration of medication or performance of medical procedure, when such medication or procedure is deemed necessary to provide comfort care or to alleviate pain." FLA. STAT. ANN. $\S$ 765.101(10) (West 2005).

${ }^{90}$ See Kathy L. Cerminara, Critical Essay: Musings on the Need to Convince Some People with Disabilities that End-of-Life Decision-Making Advocates Are Not Out to Get Them, 37 LoY. U. CHI. L.J. 343, 379-81 (2006) (stating that courts have been more cautious in approving decisions to withhold treatment from patients who 
stake in these cases-more life would be foregone, life that may be experienced. In such cases, a surrogate's decision to forego treatment is much more problematic, even when based upon the patient's preferences when competent, because the individual can experience some benefits in living and is not going to die soon anyway.

But the case of people in a permanent vegetative state is decidedly different-these knotty problems are avoided because such people have no discernible interest in continued living that is improperly overcome by judgments about the quality of their lives or that might be improperly trumped by their pre-disability sentiments.

Finally, while I claim that people in a permanent vegetative state have no interest in continued living, I am not trying to make the claim that they have no interests at all. Philosophers have argued over this point without reaching any clear consensus, except with regard to such individuals' lack of experiential interests. I have already stated that the person might be understood as having interests that her prevegetative-state autonomy be respected. I have suggested that we should avoid considering these as "present interests," however, and

are severely disabled but not permanently vegetative). See also In re Wendland, 28 P.3d 151 (Cal. 2001) (finding that the surrogate decision-maker had failed to prove by clear and convincing evidence that the severely brain damaged but conscious patient wished to refuse life-sustaining treatment or that to withhold such treatment would have been in his best interest); In re Edna M.F., 563 N.W.2d 485, 491-92 (Wis. 1997) ("a guardian [of a ward] may only direct the withdrawal of life-sustaining medical treatment, including nutrition and hydration, if incompetent ward is in a persistent vegetative state and the decision to withdraw is in the best interests of the ward"); In re Conroy, 486 A.2d 1209 (N.J. 1985) (involving a patient who might now be considered "minimally conscious," the court would not allow removal of artificial nutrition and hydration unless there were one of the following: clear evidence of prior instructions of the patient; some evidence of patient preferences plus burdens to continued treatment; or in the absence of either instructions or evidence of preferences, evidence of unavoidable pain). In Wendland, the court noted, "It is . . . worth mentioning that no decision of which we are aware has approved a conservator's or guardian's proposal to withdraw artificial nutrition and hydration from a conscious conservatee or ward." Id. at 170 . Note also that statutes that immunize participants in treatment withdrawal decisions often limit that immunity to those situations in which the patient is in a terminal condition or permanently vegetative. See ALAN MEISEL \& KATHY L. Cerminara, The Right to Die: The Law of End-OF-Life Decisionmaking $\S 8.03$ (3rd ed. 2004). For a discussion of Conroy and its requirement of pain for a successful benefits/burdens test on treatment withdrawal, see Norman L. Cantor, Discarding Substituted Judgment and Best Interests: Toward a Constructive Preference Standard for Dying, Previously Competent Patients without Advance Directives, 48 RUTGERs L. REV. 1193 (1996); JENNETT, supra note 16, at 192-94.

91 See generally Rebecca S. Dresser \& John A. Robertson, Quality of Life and Non-Treatment Decisions for Incompetent Patients: A Critique of the Orthodox Approach, 17 LAw, MED. \& HEALTH CARE 234 (1989); and Dresser, supra note 75, at 376-79. 
recognize them instead as preferences of the past that we may well want or need to respect.

The patient may also be said to have interests in her bodily integrity and in her privacy-for example, in being kept clean and in being protected from public display. My proposal for reform, however, does not rest upon my justifying that these are "interests" in any proper philosophical sense, or interests that she has a right, constitutional or otherwise, to enforce. Rather, my focus is on the responsibility of other individuals and of society, sometimes in the form of the state, to give her these things-these things which are a part of at least the barest minimum respect we owe a person.

\section{HOW THE LAW FAILS PEOPLE IN A PERMANENT VEGETATIVE STATE}

Our law fails people in a permanent vegetative state by allowing them to be perpetually fed in service to the interests of others. Even when they would have preferred to have their tube feeding discontinued and be allowed to die, the law does not ensure or even make probable that those preferences will be honored. How is this so?

A combination of factors are at work here, including our reliance on surrogate (usually family) decision-making, the lack of judicial review for decisions to continue treatment, and most of all, the presumption in favor of life-sustaining treatments, including artificial nutrition and hydration. What follows is a review of the law in general in this area and Florida law in particular, as applied to the case of Terri Schiavo.

As will become evident, the law generally, in Florida and elsewhere, not only allows patient preferences to discontinue feeding to be routinely ignored, but it never adequately acknowledges or addresses the ethical problem of imposing invasive tube feeding upon people who cannot benefit from it. The ethics of discontinuing feeding have been examined, but the ethics of force feeding rarely so.

\section{A. The Law Generally Applicable to People in a Permanent Vegetative State}

The legal architecture of end-of-life decision-making has been constructed over the last thirty years by numerous court opinions and, more recently, by statutes adopted by state legislatures, most of which follow guidelines previously set out in judicial opinions. ${ }^{92}$ While the

92 For a brief summary of state statutes and case law regarding surrogate decision-making, see JANET L. DOLGIN \& LOIS SHEPHERD, BIOETHICS AND THE LAW 
law in this area is complex, in the main there are two overriding considerations - the patient's self-determination and the patient's interests, with primary weight placed upon respecting the patient's right to self-determination. This emphasis is justified because the right to refuse medical treatment is based in the liberty interests or autonomy rights of the individual patient, and thus, to the extent we can determine what she would want done, the law generally gives effect to that preference. Sometimes, however, we cannot determine what an individual would wish (for example, if she never was competent, or if we simply lack evidence of her wishes), and in such cases courts have sometimes allowed a weighing of the burdens and benefits of a proposed course of treatment, which courts term a "best interests" analysis.

This general structure of end-of-life law currently applies to people in a permanent vegetative state. The 1976 New Jersey Supreme Court case of Karen Ann Quinlan, the first so-called "right to die" case, involved a request by Karen's father to remove her from a ventilator. ${ }^{93}$ Karen was in permanent vegetative state. ${ }^{94}$ Her father was allowed to "substitute" his judgment for his daughter's and he had the ventilator removed. ${ }^{95}$ Following the ventilator's removal, Karen lived many more years with the assistance of a nasogastric feeding tube. ${ }^{96}$ In the early days of "right to die" cases, tube feeding was not considered extraordinary medical treatment that might properly be foregone. ${ }^{97}$ That view eventually changed and there is now a general medical and legal consensus that "artificial nutrition and hydration" is a form of medical treatment that can be withdrawn under certain circumstances. ${ }^{98}$ What these circumstances might be was the subject of the 1990 Supreme Court case, In re Cruzan, in which the parents of another woman in a permanent vegetative state (Nancy Beth Cruzan) sought removal of her feeding tube a request which the Missouri Su-

743-49 (2005). For a more comprehensive explanation of the law of end-of-life decision-making, see generally MEISEL \& CERMINARA, supra note 90.

93 In re Quinlan, 355 A.2d 647 (N.J. 1976), cert. denied sub nom, Garger v. New Jersey, 429 U.S. 922 (1976).

94 Id. at 654 .

95 Id. at 666.

96 Annette E. Clark, The Right to Die: The Broken Road from Quinlan to Schiavo, 37 LOY. U. CHI. L.J. 385, 393 (citation omitted).

${ }^{97}$ See MEISEL \& CERMINARA, supra note 90, at § 6.03[G][3] \& § 5.02[E]. See also William COLBY, LONG GoOdByE: THE DEATHS OF NANCY CRUZAN 21-22 (2002) (recounting the Cruzan family's struggle to have Nancy Cruzan's feeding tube removed during the 1980s).

${ }^{98}$ Casarett et al., supra note 1, at 2607. 
preme Court had denied. ${ }^{99}$ The United States Supreme Court upheld Missouri's prohibition against removing artificial nutrition and hydration unless there was clear and convincing evidence that this was what Nancy Cruzan would have wanted, based on her own statements to that effect.

Both before and following the Cruzan case, other jurisdictions have considered the right of the person in a permanent vegetative state to refuse treatment. This issue has been considered both in court, in response to particular cases, and also by end-of-life statutes, applying more generally and prospectively. ${ }^{100} \mathrm{~A}$ number of courts have declared that the state's interests in continuing "mere biological existence" and even the individual patient's own interest in or right to life can be properly subordinated to the patient's right to refuse treatment. ${ }^{101}$ They have allowed surrogates to withdraw feeding tubes on the basis of this right when there is sufficient evidence that the patient would have wanted feeding withdrawn. ${ }^{102}$

When a patient's preferences regarding discontinuing treatment have not been clear, courts have sometimes become mired in arguments about the best interests of the permanently vegetative patient. For while there is no benefit to the patient in continued living, there is also no burden experienced by the patient. ${ }^{103}$ If a best interests analysis requires that benefits must outweigh burdens in order to justify the withdrawal of treatment (as a number of courts have held), ${ }^{104}$ then

99 Cruzan v. Dir., Mo. Dep't of Health, 497 U.S. 261, 268 (1990).

100 See cases cited supra notes 101-06. See generally John A. Robertson, Schiavo and Its (In)Significance, 35 STETSON L. REV. 101, 102-04 (summarizing legal developments since Quinlan); Cantor, supra note 90, at 1193 (summarizing standards for decision-making).

101 See Barber v. Superior Court, 195 Cal. Rptr. 484, 488 (Cal. Ct. App. 1983) (quoting President's Comm'N for the STUdy of Ethical Problems in Med. \& Biomedical \& BeHavioral RESEARCH, DeCiding to Forego Life-Sustaining TREATMENT 88 (1983)); In re Fiori, 673 A.2d 905, 910 (Pa. 1996) ("The state's interest in maintaining the PVS individual in an endless twilight state between life and death is so weak that it cannot overcome the individual's right to self-determination.") (citation omitted).

102 See, e.g., In re Fiori, 673 A.2d at 910 . See infra note 133 and accompanying text regarding differences among jurisdictions regarding the adequacy and weight of various kinds of evidence. Many state statutes also now expressly permit surrogate decision-makers to withdraw feeding tubes from such patients if to do so would be consistent with patient preferences. MEISEL \& CERMINARA, supra note 90.

${ }^{103}$ See, e.g., Mack v. Mack, 618 A.2d 744, 759 (Md. 1993).

104 See, e.g., In re Guardianship of L.W., 482 N.W.2d 60 (Wis. 1992) ("presumption is that continued life is in best interests of patient, and burden rests upon guardian to show ... that decision to withhold or withdraw treatment was in patient's best interests and was made in good faith"); In re Peter by Johanning, 529 A.2d 419 (N.J. 1987) (discussing benefits/burdens calculation of best interests test). 
perpetual feeding of the permanently vegetative patient would seem required. Some courts have avoided this difficulty in applying the best interests test by adopting the standard, but then deferring to surrogates to determine what is in the best interests of the patient. ${ }^{105}$ (Some of these courts, while deferring to surrogates on this question, note that the permanently vegetative person may be burdened by the indignity of the condition. $)^{106}$ Adopting a best interests standard but then deferring to surrogates as to what counts as burdens and benefits is unsatisfactory when the patient is in a permanent vegetative state. First, it ignores the fact that all people in a permanent vegetative state are identical in regards to their present and future interests-and thus no individualized best interests analysis is required. ${ }^{107}$ Second, because the test is essentially without any objective content, it allows the surrogate (usually a family member) to consider his or her own interests

105 See Woods v. Commonwealth, 142 S.W.3d 24 (Ky. 2004) (holding that life support can be withdrawn from never competent patient in a permanent vegetative state only upon surrogate's decision, made upon the basis of clear and convincing evidence that withdrawing life support is in the patient's best interest-but requiring no judicial review of such decisions); Guardianship of L.W., 482 N.W.2d at 60 (guardian must decide whether in vegetative patient's best interest to have lifesustaining treatment withdrawn); Rasmussen by Mitchell v. Fleming, 741 P.2d 674 (Ariz. 1987) (allowing public fiduciary as guardian to reject medical treatment for patient in a persistent vegetative state under best interests standard); In re Guardianship of Barry, 445 So. 2d 365 (Fla. Dist. Ct. App. 1984) (approving parents' decision to remove life-support systems from permanently comatose ten-month-old son).

106 See In re Rosebush, 491 N.W.2d 633 (Mich. App. 1992); Guardianship of L.W., 482 N.W. $2 \mathrm{~d}$ at 60.

107 This point is recognized in one author's critique of a 1994 English case involving a permanently vegetative patient whose wife and mother disagreed regarding the termination of artificial nutrition and hydration. The judge held in that case, In re G, [1995] 2 FCR 46, that the doctor, in reaching a decision to discontinue feeding because it was not in the patient's best interests, was required to have taken account of relatives' views. Andrew Grubb writes:

What can the relatives tell the doctor that is relevant to his 'best interests' determination? It is not clear to me what, as a matter of generality, that could be: (1) the patient's views of his own destiny? (but that seems to be irrelevant in English law except where it amounts to an advance refusal of treatment; English law does not (as yet) adopt the American-born notion of 'substituted judgment'); (2) their own views of the patient's 'best interests'? (how is this relevant so as to convert what must otherwise be 'futile' treatment into something else?); or (3) their views on what should be done because of the effects upon them: they wish to continue to care for him; they would like to let him go and mourn his death (again, how can the relatives' interests be relevant under a legal test which focuses exclusively on the patient's interests?).

Andrew Grubb, The Persistent Vegetative State: A Duty (Not) to Treat \& Conscientious Objection, in The Vegetative State: Persisting Problems IN LaW \& REGULATION 12, 18 (Pat Walsh, ed. 1999) (citations omitted). 
and the interests of other family members in making the decision-all in the name of the patient's rights.

Alternatively, some courts have determined that the best interests analysis is inapplicable to patients in a permanent vegetative state because it is impossible to determine any benefits or burdens to them of continued treatment. ${ }^{108}$ To engage in such a calculation would allow, indeed appear to require, quality-of-life judgments that courts are reluctant to permit. ${ }^{109}$ Accordingly, these courts have held that treatment can never be withdrawn from a person in a permanent vegetative state unless that decision is made in accordance with her wishes. ${ }^{110}$

A better approach would be to reformulate how we understand the best interests approach as applied to the permanently vegetative person. As Allen Buchanan and Dan Brock have explained, "The proper question for such patients ... is not 'Would withdrawal of life support best serve the patient's interest?' but rather 'Would continued support provide any benefit?""111 We lose something if we do not focus on the lack of benefit to the patient--or rather, on her lack of interest in continuing to live. We lose sight of the fact that somebody's interests are driving this train, and if not the patient's, then whose?

\section{B. Florida Law}

While courts' attempts to apply a best interests analysis to people in a permanent vegetative state have been unsatisfactory, their impulse to reach for this familiar standard, generally applicable to medical treatment decisions for incompetent patients, is understandable. There is an obvious temptation to place the permanently vegetative individual in known and familiar categories, treating them like other persons who seem somewhat similar, and therefore drawing upon a ready-

108 See, e.g., Mack, 618 A.2d at 759 ("A best interest test applied to Ronald or to any patient who is in a persistent vegetative state, who is not in pain, and who is not terminally ill, requires this Court to make a quality-of-life judgment under judicially adopted standards, without legislative guidelines."); DeGrella By and Through Parrent v. Elston, 858 S.W.2d 698, 708-10 (Ky. 1993) (stating that best interests analysis would not be adopted); Peter by Johanning, 529 A.2d at 425 ("a benefitsburden analysis . . . is essentially impossible with patients in a persistent vegetative state"). See also 73 Op. Md. Att'y Gen. 162 (1988) ("The balancing of costs and benefits to the patient that a surrogate must undertake for a terminally ill patient cannot be done in the same way for a patient who is permanently unconscious.").

109 See Mack, 618 A.2d at 759.

110 See cases cited supra note 108.

111 BUCHANAN \& BRock, supra note 75, at 132 (emphasis added). See also Rasmussen, 741 P.2d at 679 (approving surrogate's decision to place "do not resuscitate" and "do not hospitalize" orders for patient in a persistent vegetative state because of lack of benefit to her). 
made set of rules to govern our treatment of them. But those rules do not fit.

This becomes even more apparent when we look with some detail at the way Florida law provides for people in a permanent vegetative state, which essentially treats them like the incompetent terminally ill. ${ }^{112}$ The statutes that govern treatment withdrawal decisions require first a determination of what the now incompetent person would want. If there is a living will - $\mathbf{a}$ written document executed by the individual, while competent, that addresses what should be done in the situation that now exists-then the instructions of that living will may be followed. ${ }^{113}$ Typically, however, there is no living will, or its applicability to the present situation is indeterminate. ${ }^{114}$ The law then looks to an individual appointed by the patient to be his or her health care surrogate, or in the absence of such designation (again, a typical occurrence), the patient's family. ${ }^{115}$ Family members are selected according to a prioritized list according to the relationship with the patient, with spouse coming before parent. ${ }^{116}$ This individual, called the "proxy" under Florida law, is then authorized to make treatment decisions for the patient, including in certain circumstances, a decision to withhold or withdraw treatment. ${ }^{117}$ Decisions of the latter sort, however, are narrowly circumscribed. "Life-prolonging procedures" (which includes artificial nutrition and hydration ${ }^{118}$ may only be withheld or

112 Chapter 765 of the Florida Statutes contains the procedures for removing life-prolonging treatment from persons who have become incapacitated. FLA. STAT. ANN. $\S 765$ (West 2005).

${ }^{113} \S 765.302(3)$ (living will creates a rebuttable presumption of patient's wishes); In re Guardianship of Browning, 568 So. 2d 4, 17 (Fla. 1990) (same).

114 The percentage of adults in the United States completing advance directives (which include both living wills and durable powers of attorney for health care), range from 15-20 percent. Muriel R. Gillick, Advance Care Planning, 350 NEw ENG. J. MED. 7, 8 (2004). For a recent and thorough critique of living wills, see Angela Fagerlin \& Carl E. Schneider, Enough: The Failure of the Living Will, HastINGS CENTER ReP., Mar.-Apr. 2004, at 30 (2004).

115 Meisel \& Cerminara explain that most states have adopted surrogate decision-making statutes for the purpose of making clear

what is at least implicit in the case law: that the customary medical professional practice of using family members to make decisions for patients who lack decisionmaking capacity and who lack advance directives is legally valid, and that ordinarily judicial proceedings need not be initiated for the appointment of a guardian.

MEISEL \& CERMINARA, supra note 90 , at $\$ 8.01$.

$116 \$ 765.401$.

$117 \S 765.401(3)$.

118 "Life-prolonging procedure" means, under the Florida statute, "any medical procedure, treatment, or intervention, including artificially provided sustenance and hydration, which sustains, restores, or supplants a spontaneous vital function." $\S$ 
withdrawn if the patient is in one of three conditions: ${ }^{119}$ a terminal condition, ${ }^{120}$ an end-stage condition (such as advanced Alzheimer's), ${ }^{121}$ or a persistent vegetative state. ${ }^{122}$ The existence of the condition must be verified by two physicians. ${ }^{123}$ Further, lifesustaining treatment may only be withdrawn if the surrogate determines on the basis of clear and convincing evidence that withdrawing treatment is in accordance with the patient's wishes or, if there is insufficient evidence of the patient's wishes, if withdrawing treatment is in the patient's best interests. ${ }^{124}$ The "clear and convincing" standard

765.101(10). Excluded from the definition is "the administration of medication or performance of medical procedure, when such medication or procedure is deemed necessary to provide comfort care or to alleviate pain." $\S 765.101(10)$.

${ }_{119}$ It is important to note that both the Florida statutes, $\S 765.106$, and the Florida Supreme Court in In re Guardianship of Browning, 568 So. 2d 4, 11 (Fla. 1990 ), indicate that individuals may have a common law or constitutional right to refuse treatment that is greater than what is set out in the statutory scheme. Therefore, it is possible that an individual can have life-prolonging procedures withdrawn even though he or she does not fall into one of these three categories. In In re Browning, the court approved a surrogate's decision to withdraw a feeding tube from a woman whose death was not "imminent" and who was not in a permanent vegetative state (the two conditions at that time included in the Florida statutes for which a surrogate could withdraw life-prolonging treatment). Id. at 17.

${ }^{120}$ A "terminal condition" means "a condition caused by injury, disease, or illness from which there is no reasonable medical probability of recovery and which, without treatment, can be expected to cause death." $\S 765.101(17)$.

${ }^{121}$ An "end stage condition" is "an irreversible condition that is caused by injury, disease, or illness which has resulted in progressively severe and permanent deterioration, and which, to a reasonable degree of medical probability, treatment of the condition would be ineffective." $§ 765.101(4)$. This term is commonly understood to embrace advanced dementia, such as that caused by Alzheimer's, which is steadily progressive, incurable and ultimately fatal. See Op. Md. Att'y Gen. 00-029 (2000) (interpreting a statute similar to Florida's).

122 The Florida statutes define "persistent vegetative state" as "a permanent and irreversible condition of unconsciousness in which there is: (a) The absence of voluntary action or cognitive behavior of any kind. (b) An inability to communicate or interact purposefully with the environment." $\S 765.101(12)$.

$123 \S 765.306$.

124 This standard is clearly delineated with respect to surrogates who are designated by statute rather than appointed by the patient through an advance directive. $\S 765.401(3)$. Under Florida law, such a surrogate is called a "proxy." See § 765.401. The statutes do not specifically require this evidentiary standard with respect to a surrogate appointed by an advance directive. See $\S 765.205$ for a description of the responsibilities of the appointed surrogate. The statute provides that health care decisions must be made as the surrogate

believes the principal would have made [them] under the circumstances if the principal were capable of making such decisions. If there is no indication of what the principal would have chosen, the surrogate may consider the patient's best interest in deciding that proposed treatments are to be withheld or that treatments currently in effect are to be withdrawn. 
of evidence lies between the usual standard of evidence in a civil case, that of preponderance of the evidence, and the usual standard in a criminal case, that of beyond a reasonable doubt. ${ }^{125}$ Judicial approval of a surrogate's decision to withdraw treatment is not required, ${ }^{126}$ but immunity for those involved in the decision to withdraw treatment depends upon the surrogate's compliance with the statute. ${ }^{127}$ Healthcare providers may therefore refuse to withdraw treatment on the basis of a surrogate's instructions unless the surrogate's decision is judicially sanctioned. Other family members or other interested parties may also challenge a surrogate's decision to withdraw treatment by instituting a judicial proceeding to put the surrogate to his proof. ${ }^{128}$

Florida's law on end-of-life decision-making is in many respects more liberal than the law of other states. For example, Florida statutes make clear that artificial nutrition and hydration is a form of medical treatment that may be withheld or withdrawn under the same conditions as other forms of medical treatment, ${ }^{129}$ whereas some states make it more difficult for the surrogate to withhold or withdraw artificial nutrition and hydration than other forms of treatment. ${ }^{130}$ Florida

$\S 765.205$. The surrogate is given explicit authority to consent to withholding or withdrawing life-prolonging procedures as long as the patient is in one of the three conditions described above. $\S 765.305$. This decision can be challenged by the patient's family, or some other interested party, if " $[\mathrm{t}]$ he surrogate or proxy's decision is not in accord with the patient's known desires or the provisions of this chapter." $\$ 765.105$. The Florida Supreme Court's opinion in In re Guardianship of Browning suggests that the "clear and convincing" standard would apply equally to surrogate and proxy decisions to withdraw life-prolonging treatment, although this is not entirely clear. 568 So. 2d 4, 16 (Fla. 1990).

${ }^{125}$ The majority opinion in Cruzan noted that clear and convincing evidence was that which

produces in the mind of the trier of fact a firm belief or conviction as to the truth of the allegations sought to be established, evidence so clear, direct and weighty and convincing as to enable [the factfinder] to come to a clear conviction, without hesitancy, of the truth of the precise facts in issue.

Cruzan v. Dir., Mo. Dep't of Health, 497 U.S. 261, 285 n.11 (1990) (citations omitted).

126 Browning, 568 So. 2d at 14-15.

127 See $\$ 765.109$.

128 See $\$ 765.105$.

129 See $\S 765.101$ (including "artificially provided sustenance and hydration" in the definition of "life-prolonging procedures" that may be withheld or withdrawn in certain instances).

${ }^{130}$ See, e.g., MinN. STAT. ANN. $\$ \S 145 B .03(2)(\mathrm{b})(2), 145 B .13(2)$ (West 2005) (discussing requirements for creating a living will and that food and hydration must be administered unless the patient clearly documents otherwise); OKLA. STAT. ANN. tit. 63, $\S \S 3080.4(A)(1), 3101.4(B)$ (West 2004) (describing the presumption of nutrition and hydration and providing a sample format for an advance directive). See generally Alan Meisel, Barriers to Foregoing Nutrition and Hydration in Nursing 
has added "end-stage condition" to its list of conditions in which lifesustaining treatment may be withheld or withdrawn, whereas other states limit treatment withdrawals to the terminally ill or those in a permanent vegetative state. ${ }^{131}$ In the Florida courts, judges have allowed evidence of the patient's values and personality in determining whether the surrogate is making the decision that the patient would make, ${ }^{132}$ whereas some other states have imposed far more stringent requirements with regard to the type of evidence that may be used to support the surrogate's decision-some insisting, for example, on statements made by the patient about the particular condition in which she now finds herself, or about the particular sort of treatment (e.g., ventilator, feeding tube) that might be withdrawn. ${ }^{133}$ Finally, Florida also allows a surrogate decision-maker to withhold or withdraw treatment even in the absence of evidence that it is what the patient would want, if the surrogate has clear and convincing evidence that nontreatment would be in the patient's best interests-for example, if treatment would prolong the patient's life, but only with significant pain or other burdens. ${ }^{134}$ Many other states explicitly eschew such a best interest analysis on the grounds that it would permit a surrogate

Homes, 21 AM. J. L. \& MED. 335 (1995) (discussing the greater reluctance by medical professionals to remove hydration and feeding tubes than to cease other types of lifesustaining treatment).

131 Meisel \& Cerminara, supra note 90, at $\S 8.03$. See, e.g., Mont. Code ANN. $\S 50-9-106(1)$ (2005) ("terminal condition"); N.C. GEN. STAT. $\S 90-322(a)$ (2006) (terminal and incurable condition or persistent vegetative state).

${ }_{132}$ See In re Guardianship of Schiavo (Schiavo II), 792 So. 2d 551, 560 (Fla. Dist. Ct. App. 2001) ("the trial judge . . . properly considered evidence of Mrs. Schiavo's values, personality, and her own decision-making process.").

133 There are intermediate positions between these, each court adopting its own view of the adequacy and weight of various kinds of evidence. For example, some states have required evidence that the patient had actual views on the subject prior to incompetency, rather than allowing the surrogate to take account of all relevant knowledge of the patient's life, values, and personality, in addition to statements made by the patient, in order to determine what the patient would choose now, if he or should could form and communicate a choice. See, e.g., Mack v. Mack, 618 A.2d 744,758 (Md. 1993). That Florida adopts the latter view of what some courts have called "substituted judgment," is evident in the Florida appellate court's affirmance of the guardianship court's ruling that "clear and convincing evidence at the time of trial supported a determination that Mrs. Schiavo would have chosen in February 2000 to withdraw the life-prolonging procedures." In re Guardianship of Schiavo (Schiavo III), 800 So. 2d 640, 642 (Fla. Dist. Ct. App. 2001). For an explanation of the different approaches that have emerged with respect to substituted judgment in this context, see Cantor, supra note 90, at 1193.

134 See FLA. STAT. ANN. $\S 765.205$ (b) (West 2005) (for surrogates appointed by advance directive); $§ 765.401$ (for surrogates called "proxies," designated by statute). 
to engage in unacceptable evaluations of the "quality of life" of the patient.

But Florida, like the law of most states, still retains a presumption in favor of continued treatment. In In re Browning, a Florida appeals court stated, "In making this difficult decision, a surrogate decisionmaker should err on the side of life. . . . In cases of doubt, we must assume that a patient would choose to defend life in exercising his or her right to privacy." 136 This statement was quoted with approval by the Second District Court of Appeals in upholding the initial decision of the trial court to remove Terri Schiavo's feeding tube. ${ }^{137}$

The presumption is also embedded in the statutory system for end-of-life decision-making in the requirement that life-sustaining treatment be withheld or withdrawn only upon clear and convincing evidence that the decision is according to the patient's preferences or her interests. ${ }^{138}$ In the absence of evidence reaching this standard (even in the presence of a preponderance of the evidence that the patient would want treatment withdrawn), treatment may not be withdrawn. Moreover, if the surrogate prefers treatment for the patient, rather than wishes to withdraw it, there is no obvious procedure or clear standards by which to challenge that decision as contrary to the patient's preferences. The exception may be if the patient had left a very specific living will that the surrogate appeared to disregard. ${ }^{139}$

${ }^{135}$ See, e.g., Cruzan v. Harmon, 760 S.W.2d 408 (Mo. 1988); In re Storar, 420 N.E.2d 64 (N.Y. 1981); MEISEL \& CERMINARA, supra note 90, at $\$ 4.07$ [B]; and Cathaleen A. Roach, Paradox and Pandora's Box: The Tragedy of Current Right-toDie Jurisprudence, 25 U. MICH. J.L. REFORM 133 (1991) (arguing for uniformity among state laws).

${ }^{136}$ In re Guardianship of Browning, 543 So. 2d 258, 273 (Fla. Dist. Ct. App.) (recognizing state constitutional rights to refuse medical treatment on behalf of incompetent patients).

137 In re Guardianship of Schiavo (Schiavo I), 780 So. 2d 176, 179 (Fla. Dist. Ct. App. 2001) ("We reconfirm today that a court's default position must favor life.").

138 MEISEL \& CERMINARA, supra note 90, at $\$ 3.27$ [A] ("Clear and convincing evidence' has become the clearly dominant accepted standard of proof in end-oflife cases. Clearly, it applies in court cases; it similarly appears that this standard of proof is to be used in nonjudicial review of end-of-life decisionmaking.").

139 This appeared to be the situation in another recent, highly unusual Florida case, involving a man named Hanford Pinette. In the fall of 2004 , the doctors of $\mathrm{Mr}$. Pinette, a seventy-three-year-old man, certified that he was in a terminal condition. He was suffering from chronic failure of his respiratory, circulatory and renal systems. In 1998 he had signed a living will that, according to news reports, directed that life-sustaining treatment be withheld in these circumstances. He had also executed a health care power of attorney, naming his wife of many years as his health care surrogate. She disagreed with the doctors about the state of her husband's condition and the application of his living will, saying that he still enjoyed watching sports on television with other family members and that he was responsive. She insisted that he 
But otherwise, surrogate decisions in favor of treatment are likely to go unchallenged unless they are causing the patient unreasonable pain or other burdens, in which case health care providers or other family members may attempt to intervene. With respect to the patient in a permanent vegetative state, there would be no unreasonable pain or burdens that would be experienced by the patient, and so the grounds for intervening and challenging the surrogate's decision are essentially absent.

Thus, tube feeding for the person in a permanent vegetative state may be discontinued in certain circumstances, but it will depend upon who the surrogate decision-maker is whether feeding will continue or not. The surrogate who decides against feeding can have a difficult time making the case for removal of the feeding tube. Michael Schiavo is one such surrogate who ultimately received court orders to permit feeding to be discontinued, but only after a long and bitter battle, during which Terri Schiavo became both the pawn and the endgame.

More importantly, however, the battle would never have been fought, a decision to discontinue feeding would never have been made, and Terri would likely continue to live for a few more decades, against her wishes and solely because of others' interests and ideologies, if Michael Schiavo had been replaced with Robert or Mary Schindler. ${ }^{140}$ Under Florida law (and again, most state laws) their decision to continue to tube feed Terri would most likely not have come under judicial review. In theory, Michael Schiavo could have challenged the decision to continue to tube feed Terri, but there would be no clear basis for that challenge. Surrogates making decisions to with-

would not yet want to die. Hospital administrators petitioned a circuit court to enforce the living will over the wife's objection, which it did. See Mike Branom, Judge Upholds Living Will, TAllaHASSEE DeMOCRAT, Nov. 24, 2004, at B6; Anthony Colarossi \& Melissa Harris, Living-Will Questions Persist: A Lake Case Causes Some to Wonder if Their Wishes Will Be Followed, ORLando Sentinel, Nov. 25, 2004, at B1. For commentary questioning the appropriateness of the court's decision, see Lois Shepherd, Shattering the Neutral Surrogate Myth in End-of-Life Decisionmaking: Terri Schiavo and Her Family, 35 CUMB. L. REV 575 (2005).

140 Either Michael or one of Terri's parents could have qualified as the surrogate for Terri, but Michael had priority as her spouse. The surrogate decision-making statute in Florida provides for the following people to serve as surrogate (called the "proxy"), in the priority listed: (a) a guardian appointed by a court (although the statute made clear that one did not need to be appointed); (b) the patient's spouse; (c) an adult child of the patient (or a majority of adult children reasonably available for consultation if there is more than one adult child); (d) a parent of the patient; (e) the adult sibling of the patient (or a majority of the adult siblings reasonably available for consultation if there is more than one adult sibling); (e) an adult relative of the patient; or (f) a close friend of the patient. Fla. StaT. ANN. $\S 765.401$ (West 2005). 
draw treatment can be put to their proof, but decisions to continue unburdensome treatment are presumptively valid, even preferred.

The result is that surrogates' interests in continuing to feed the individual in a permanent vegetative state prevail under Florida's and most states' existing statutory scheme regarding the cessation of lifesustaining treatment. These laws unreasonably place into the hands of others the power to continue feeding patients in a permanent vegetative state when it is not for their benefit, nor even according to their wishes, to be fed.

Why do we give surrogates so much power? The family's role in end-of-life decision-making is generally justified on the grounds that family members are the persons most likely to know what a patient's preferences would be regarding treatment or nontreatment and that family members most likely will, through natural bonds of affection, act to protect the patient's interests. ${ }^{141}$ The fact that most patients appear to want a family member, rather than a physician or court or other stranger, to make such decisions for them lends further support to family participation in end-of-life decision-making. ${ }^{142} \mathrm{We}$ might also justify family involvement in part on the grounds that close family members have interests of their own that might well deserve protection, as long as those interests do not take precedence over the patient's interests. ${ }^{143}$ Family members may need involvement in the decision-making as part of their role of caring for the patient; they may need some delay in a decision to withdraw treatment; they likely

141 See President's Comm'n For the Study of Ethical Problems IN MED. \& BIOMEDICAL \& BEHAVIORAL RESEARCH, DECIDING to Forego LifE-Sustaining TREATMENT: ETHICAL, MEDICAL, AND LEGAL ISSUES IN TREATMENT DECISIONS 126-28 (1983).

${ }^{142}$ See Stephen C. Hines et al., Dialysis Patients' Preferences for FamilyBased Advance Care Planning, 130 ANNALS INTERNAL MED. 825, 825 (1999) (explaining that studies have shown that "patients do not trust their physicians to honor their wishes. Instead, they trust their families and prefer that their families speak for them"); In re Jobes, 529 A.2d 434, 446, n.11 (N.J. 1987) (reporting on surveys); Dallas M. High, All in the Family: Extended Autonomy and Expectations in Surrogate Health Care Decision-Making, 28 GERONTOLOGIST 46 (1988).

${ }_{143}$ See generally Shepherd, supra note 139 (arguing for some deference to family member surrogate preferences in the case of terminally ill patients, as long as decisions are not clearly against the patient's interests or known preferences); and Kathleen M. Boozang, An Intimate Passing: Restoring the Role of Family and Religion in Dying, 58 U. PITT. L. REV. 549 (1997) (arguing for legal changes to respect the family's interests in end-of-life decisions). Professor Boozang's proposal calls for deference to family decision-making without the restraints of a "substituted judgment" or "best interest" rubric and with particular respect for the family's religious beliefs. Id. at 552-54. See also Nancy K. Rhoden, Litigating Life and Death, 102 HARV. L. REV. 375 (1988) (proposing legal presumption in favor of the choice of a close family member). 
need conversation with health care providers that involves a sharing of information about the patient and her welfare.

In the case of the patient who is likely to die shortly from the natural progression of his disease process, deference to a family member's decision to continue treatment may be warranted as long as treatment does not cause the patient to suffer and is not clearly contrary to his known preferences. Our law's deference to family members may also mean, however, that sometimes family members may continue treatment when it is against the patient's known preferences or interests. Still, we may prefer a system, such as the one we have, in which we do not provide judicial oversight of such decisions because, on the whole, family member surrogates do put the patient first, ahead of their own considerations; because imposing judicial or similar scrutiny would cause added suffering to the family; or because we believe that health care providers can generally provide a check against the provision of treatment that would actually burden rather than benefit the patient. For the incompetent, terminally ill patient, this may be the appropriate method of making treatment decisions. ${ }^{144}$ In such cases, the primary effect of treatment will be to cause a delay in the inevitable death of the patient. But this system for end-of-life decisionmaking for the terminally ill has far different consequences when applied to people in a permanent vegetative state.

If the "correct" treatment decision could be determined objectively-where the evidence of patient preferences was clear or the interests of the patient clearly pointed to some treatment decision over another - then "incorrect" treatment decisions (that is, decisions to treat, when nontreatment is preferable and vice versa) are, in the case of the terminally ill patient, at least in some respects limited by the limited life span of the patient who must bear the consequences of that decision. There may be unnecessary pain and suffering caused by the surrogate's mistaken judgment, or a patient may live his last days in a debilitating state that he had wished to avoid. But the presumption in favor of continuing treatment does not have the long-term consequences that it does for the person in a permanent vegetative state. If the surrogate has allowed his or her own interests (or the interests of others) to dictate the continued treatment of the patient, such instrumental use of the patient will, for the dying patient, be short-lived, whereas for the patient in a permanent vegetative state, such instrumental use could be potentially decades-long.

The law in Florida gives at least some limited recognition to the unfortunate state of limbo into which the permanently vegetative pa-

144 See generally Shepherd, supra note 139. 
tient may fall. It permits the withdrawal of feeding and hydration for patients who do not have a living will and have no family member or other personal surrogate to speak for them. ${ }^{145}$ In such cases, a social worker can, in conference with a hospital or nursing home ethics committee, authorize the withdrawal of feeding if they agree that such is in the patient's best interests. ${ }^{146}$ This exception is for permanently vegetative patients only. ${ }^{147}$ The exception appears to suggest at least two things: first, that assessing the appropriateness of continued feeding of the vegetative patient might be achieved by objective measures, applicable to all such patients rather than requiring an individualized analysis; and two, that the operation of such objective measures could quite understandably lead to discontinuation of feeding. Under this exception, if Terri Schiavo had not had a family member or close friend willing to serve as her surrogate, her feeding tube could have be discontinued upon the decision of a social worker at the institution in which she was cared for, upon the agreement of its ethics committee.

This exception is a step in the right direction, ${ }^{148}$ in that it recognizes that patients in a permanent vegetative state are not like dying patients: an early decision to treat, left unchecked, may lead to perpetual feeding of patients in a permanent vegetative state when it does not benefit them.

\section{THE INTERESTS OF OTHERS}

If continued tube feeding of people in a permanent vegetative state is not done to satisfy their preferences, or to benefit them, what sorts of other interests are driving the decision for continued treatment? Here the case of Terri Schiavo is again instructive. ${ }^{149}$

That other people used Terri Schiavo for their own purposes, or sometimes, as we will see, were just accused of doing so, makes clear that under current law, others' interests can and sometimes do improperly influence the decision to continue feeding patients in a permanent vegetative state. These interests may be financial, ideological, or personal.

\footnotetext{
145 See Fla. Stat. ANN. $§ 765.404$ (West 2005).

$146 \S 765.404$.

$147 \S 765.404$.
}

148 It is not obviously, in my view, the best approach, as it still appears to allow a social worker and ethics committee to determine that continued feeding is in the permanently vegetative patient's best interests. Moreover, it only applies when no family member or close friend will serve as surrogate, a limited group of people.

149 For a concise summary of the facts in the Schiavo controversy, see Lois Shepherd, Terri Schiavo: Unsettling the Settled, 37 LOY. U. CHI. L.J. 297 (2006). 


\section{A. Financial Interests}

During the battle over Terri Schiavo's feeding tube, the Schindlers accused Michael Schiavo of having a financial interest in discontinuing feeding, while Michael Schiavo countered that the Schindlers had a financial interest in keeping Terri Schiavo alive. The arguments, on both sides, looked like this.

Michael Schiavo, in 1993, successfully sued certain health care providers involved in Terri's care for failing to diagnose her as bulimic. ${ }^{150}$ According to the allegations in the lawsuit, Terri's bulimia caused a potassium imbalance in her body that brought on a cardiac arrest, which led to her brain being deprived of oxygen and her ultimate permanent vegetative state. ${ }^{151}$ Part of the award in that case, $\$ 750,000$, was for Terri's continued care. ${ }^{152}$ According to a guardian ad litem's report, this money was placed in a trust fund, which was managed by an independent trustee and over which Michael Schiavo had no control. ${ }^{153}$ But the Schindlers argued that if Terri died, those remaining monies would become part of Terri's estate, which Michael Schiavo would inherit. ${ }^{154}$ Thus, one of their arguments for removing Michael Schiavo as the guardian of Terri Schiavo was that he was motivated not to protect her interests, but to further his own, by hastening Terri's death, saving what was left from the judgment for her care, and securing it for himself. ${ }^{155}$ The governor of Florida, as part of his justification for intervening in the Schiavo case, also made public reference to Michael Schiavo's financial interests in Terri's death. ${ }^{156}$

The Florida Court of Appeals, when confronted early on with this argument, countered in two ways. First, the Court noted that surrogates will generally have financial interests that are bound up with the decision to continue or discontinue feeding - the people who are ei-

${ }^{150}$ WoLfSON, supra note 13 , at 8-9.

151 Id.

152 The Wolfson Report places the figure at $\$ 750,000$ for economic damages, while the original court order in the Schiavo case places the figure at $\$ 700,000$. Id ; In re Guardianship of Schiavo, No. 90-2908GD-003, 2000 WL 34546715 (Fla. Cir. Ct. Feb. 11, 2000) (order authorizing removal of Terri Schiavo's feeding tube).

153 WolfSON, supra note 13 , at 9.

154 In re Guardianship of Schiavo (Schiavo I), 780 So. 2d 176, 178 (Fla. Dist. Ct. App. 2001).

${ }_{155} I d$.

156 See On the Record with Greta Van Susteren: Is a Florida Judge About to Throw Out a Law Keeping Terri Schiavo Alive? (Fox News television broadcast Jan. 9, 2004), transcript available at http://www.foxnews.com/story/0,2933,108134,00. html (Ken Connor, attorney for Governor Jeb Bush, stating, "The testimony that's been offered by the husband, who has a stake in her death and who stands to gain financially and otherwise by her death, is uncorroborated."). 
ther designated as surrogates by the patient, or who are designated by statute, are often people who stand to inherit a portion of the estate of the patient. ${ }^{157}$ Second, the Schindlers could also be understood as having a financial interest in the decision whether to continue to feed Terri. If they were able, through legal maneuvering, to keep Terri alive long enough so that Michael Schiavo would seek a divorce in order to continue his own life with perhaps a new wife, then they would stand to inherit from Terri's estate. They would, accordingly, have a financial interest in keeping her alive until Michael Schiavo divorced her, and then authorize the withdrawal of the feeding tube. ${ }^{158}$

It is important to note that while the trial and appellate courts acknowledged that Michael Schiavo might have financial interests in Terri's death, and the Schindlers in Terri's life, they did not ascribe such motives to either side. ${ }^{159}$ In fact, in an early filing with the court, Michael Schiavo noted that he had formally offered to divest himself of any financial interest in Terri's estate. ${ }^{160}$ By the time the feeding tube was removed in March of 2005 , there was very little, if any, money left. ${ }^{161}$

But the argument about such financial interests is important because, whether or not such interests motivated the parties in the Schiavo case, they clearly can motivate the parties in other cases. Medical malpractice judgments or settlements associated with the continued care of a person in a permanent vegetative state should not be structured in a way that can influence the decision of whether or not to continue feeding such a person. More specifically, any savings that are made because of a decision to discontinue feeding should not devolve to the person who makes that decision.

Perhaps it is not possible to eliminate entirely the financial interests of others in the future treatment of the patient, but now that it has become clear that they can play a role - and it is difficult to find any proper aspect to that role - then the law should be modified to reduce these influences.

${ }^{157}$ Schiavo I, 780 So. $2 \mathrm{~d}$ at 178.

158 See id.

159 Id.

160 Wolfson, supra note 13, at 12. The Gaurdian Ad Litem's report explains that Michael Schiavo described this formal offer in a Suggestion of Bias that he filed against an earlier guardian ad litem who had considered Michael as having a potential conflict of interest because of the residual funds in Terri's trust account. Id.

${ }^{161}$ Mick Schneider, Schiavo Dies at Hospice, STAR-LeDGER (Newark, N.J.), Mar. 31, 2005, at 1 . 


\section{B. Ideological Interests}

Clearly, the case of Terri Schiavo involved the attachment of ideological interests to her fate. The Schindlers were supported in their efforts to keep Terri alive by numerous right-to-life and disability rights groups. Their support varied from the financial to the political, from appeals through the media to filings of amicus briefs. ${ }^{162} \mathrm{On}$ its face, such advocacy might have signaled something very positive, if the concern had truly been about Terri's fate, wishes, and interests. However, much of the work of these groups in connection with Terri's case did not have such focus and concern, but was substantially about other causes that such groups wished to advance, such as the protection of fetuses and embryos for right-to-life groups and the protection of severely disabled, but not permanently vegetative, patients for disability rights groups. As a check on whose interests they were seeking to advance we might ask, which among these groups stood up for Terri's medical privacy in addition to her "right to life"? The answer, as far as I can tell, was none.

In Terri's case, adherence to or faith in certain ideologies became important as a political matter as well. It appeared to be in President George W. Bush and Florida Governor Jeb Bush's political interests, and those of many state and U.S. legislators, to intervene in Terri's case with special legislation designed to cause the reinsertion of her feeding tube. In October 2003, Florida passed Terri's Law, ${ }^{163}$ allow-

162 See Stephen Nohlgren \& Tom Zucco, Schiavo Case Has Myriad Fund Sources, St. PETERSBuRg TIMES, Mar. 28, 2005, at 1A. Examples of those who supported the Schindlers are the Alliance Defense Fund, Life Legal Defense Foundation, RightMarch, the Family Research Council. Id. The American Civil Liberties Union provided most of the appellate work for Michael Schiavo. Id.

${ }^{163}$ Terri's Law essentially only applied to Terri Schiavo. It read:

Section 1. (1) The Governor shall have the authority to issue a one-time stay to prevent the withholding of nutrition and hydration from a patient if, as of October 15, 2003:

(a) That patient has no written advance directive;

(b) The court has found that patient to be in a persistent vegetative state;

(c) That patient has had nutrition and hydration withheld; and

(d) A member of that patient's family has challenged the withholding

of nutrition and hydration.

(2) The Governor's authority to issue the stay expires 15 days after the effective date of this act, and the expiration of that authority does not impact the validity or the effect of any stay issued pursuant to this act. The Governor may lift the stay authorized under this act at any time. A person may not be held civilly liable and is not subject to regulatory or disciplinary sanctions for taking any action to comply with a stay issued by the Governor pursuant to this act. 
ing the governor to order the reinsertion of the tube, a law declared unconstitutional by the Florida Supreme Court in fall $2004 .{ }^{164}$ In March 2005, the U.S. Congress passed special legislation allowing for federal court review of the Schindlers' claims that Terri's federal rights were being violated when her tube had once again been removed according to a state court order. ${ }^{165}$ By supporting this special legislation, civic leaders were able to show their solidarity with certain religious organizations on the issue of protecting vulnerable life.

With Terri Schiavo, the extent to which political and ideological groups took up (what they asserted to be) her cause, and benefited from using her as their focal point in making ideological and political points, is certainly unusual. Terri's case, however, reveals but an exaggeration of how the ideological interests of others can determine what is done with an individual's life. One way in which the ideological interests of others in the treatment decisions of a person in a permanent vegetative state may come into play is in the recommendation of physicians to continue feeding because they, the physicians, believe that feeding is the "right" thing to do. Of course, not all physicians believe that feeding a person in a permanent vegetative state is ethically required, and the American Medical Association and other physicians' groups have adopted policies to respect patient and/or family wishes in this regard. ${ }^{166}$ But a substantial number do believe that feeding is always required and their beliefs about this matter are given substantial weight by family members who cede to the physicians' preferred course of treatment. ${ }^{167}$ In fact, often little discussion takes

(3) Upon the issuance of a stay, the chief judge of the circuit court shall appoint a guardian ad litem for the patient to make recommendations to the Governor and the court.

Section 2. This act shall take effect upon becoming a law.

S.B. 12-E, H.B. 35-E (Fla. 2003).

164 Bush v. Schiavo, 885 So. 2d 321 (Fla. 2004).

165 Relief of the Parents of Theresa Marie Schiavo, Pub. L. No. 109-3, 119 Stat. 15 (2005),

${ }_{166}$ See Task Force Report, Part I, supra note 16, at 1499-1500.

167 See Kirk Payne et al., Physicians' Attitudes about the Care of Patients in the Persistent Vegetative State: A National Survey, 125 ANN. INT. MED. 104 (1996). Payne et al. report that 29 percent of medical directors surveyed and 47 percent of neurologists surveyed believe that artificial nutrition and hydration should generally be provided to individuals in a persistent vegetative state. At the same time, 89 percent of medical directors and 88 percent of neurologists surveyed believe it is ethical to withhold or withdraw artificial nutrition and hydration according to the instructions of a living will or a patient's surrogate. Id. See also Casarett et al., supra note 1, at 2607 (explaining that patients and families are often ill-informed about the risks and benefits of artificial nutrition and hydration); COLBY, supra note 97, at 21-22 (describing the experience of Nancy Cruzan's parents in giving their consent to the surgical 
place about the issue and in the absence of any requirement for periodical revisiting of the decision, feeding can continue for many years on the basis of nothing more substantial than physicians' preferences. ${ }^{168}$ Yet, while patients and their family members often follow physicians' recommendations regarding treatment, the decision here is not a medical one. Yes, tube feeding will sustain life (a medical judgment), but the ultimate question to be answered for the patient is whether that life should be sustained, a question that doctors are no more qualified to answer than anybody else. So, in a sense, while Terri lived for a number of years, in part, for right-to-life, religious, and disability rights groups, rather than for herself, so too are many other patients in a permanent vegetative state living, at least in part, for physicians who recommended that their feeding be continued.

\section{Personal Interests}

The personal non-financial interests involved in the Terri Schiavo case and in the case of many patients in a permanent vegetative state are naturally somewhat difficult to unpack. They typically involve close human relationships, which can be intricate (to put it nicely) and messy (to put it more bluntly). On the one hand, as a society we want to recognize, support, and value such relationships to the extent they are beneficial to those involved. We assume, with respect to spouses and family members, that such relationships are beneficial. To some extent, our laws regarding the cessation of life- sustaining treatment do, and I think should, exhibit some deference to the importance of such marital, familial and other relationships. However, that is not, and should not be, the law's focus. Rather, that focus is on what the patient would want or, if that is impossible to know, on the patient's interests. The family's interests are not directly at issue and certainly are not supposed to drive decisions about treatment. That does not mean that the family's involvement is not respected and valued. It simply means that that involvement is supposed to be directed toward the patient and not the self.

With respect to Terri Schiavo, the Schindlers accused Michael Schiavo of wishing to essentially dispose of Terri so that he might go

insertion of a feeding tube for their daughter). But see Lindsay A. Hampson \& Ezekiel J. Emanuel, The Prognosis for Changes in End-of-Life Care After the Schiavo Case, 24 Health AfFaIRS 972 (2005) (predicting increased conflict, following Schiavo, between physicians who wish to terminate treatment and family members who wish to continue it).

Cruzan family).

${ }_{168}$ See generally COLBY, supra note 97 (describing the experience of the 
on with his new life with his girlfriend of several years and the two children they had had together. ${ }^{169}$ Michael Schiavo countered that he was only trying to advocate for what Terri would have wanted, as evidenced by statements that she made to him and others. ${ }^{170}$ That, he said, is why he refused to divorce Terri, because then she would be subjected to continued life against her wishes by the Schindlers. ${ }^{171}$

The Schindlers' personal interest in Terri's continued life can and should have been challenged in the same manner as Michael Schiavo's alleged interest in Terri's demise. There are several possible ways of understanding their interests, but the most likely and also the most charitable, are that they had an interest in her continued life simply because they loved her.

The law might be understood as valuing such caring connections by designating family members as the default surrogates when the patient has not appointed one. But even if that is somewhat true, the idea behind designating family members as surrogates is not to advance the surrogate's own interests before, or instead of, the interests of the patient. Rather, as discussed above, allowing family members to step in to speak for the patient is justified on the grounds that the surrogate will be most motivated to advocate for the patient's interests and will also know, better than a stranger or even a friend, what the patient would want if she could decide for herself.

But the Schindlers' arguments for removing Michael Schiavo as guardian and replacing him with one of the two of them did not emphasize their superior ability to discern, or their greater inclination to respect, Terri's wishes. In fact, a guardian ad litem's comprehensive report to the Florida governor and the court revealed the Schindlers' willingness to push for continued feeding of Terri Schiavo even if they believed she would have wanted to die. ${ }^{172}$ The report discloses that at one point in the proceedings to determine what should be done about Terri's continued feeding, members of the Schindler family were questioned about their commitment to do everything medically possible to keep Terri alive. ${ }^{173}$ According to the guardian ad litem, they were asked about a number of "gruesome examples." 174 For example, they were asked whether they would agree to Terri's foregoing

169 See Jamie Thompson, She's the Other Woman in Michael Schiavo's Heart, St. PeTERSBURG Times, Mar. 26, 2005, at 1A.

${ }^{170}$ Gail Gibson, Schiavo Dies, Anger Remains, BALT. SUN, Apr. 1, 2005, at $1 \mathrm{~A}$.

171 Id.

172 WOLFSON, supra note 13 , at 14.

${ }^{173} \mathrm{Id}$.

174 Id. 
a highly invasive heart surgery if Terri at that point also had had all four limbs amputated because of gangrene. ${ }^{175}$ They replied that yes, the surgery should be done. ${ }^{176}$ The report continues, "Within the testimony, as part of the hypotheticals presented, Schindler family members stated that even if Theresa had told them of her intention to have artificial nutrition withdrawn, they would not do it."177

The various positions that the Schindlers took throughout the litigation and media war on the issue of continuing feeding emphasized either that there was hope for Terri's recovery or that feeding is a form of basic care that cannot be withdrawn-not that they, better than Michael Schiavo, would have respected Terri's autonomy by attempting to duplicate the decision she would make. Moreover, their answers to the hypothetical "gruesome examples" with which they were presented showed their reluctance to engage in any sort of balancing between the burdens and benefits of treatment options (in other words, concern for Terri's interests)-rather their position seemed simply that life must be pursued at all cost.

The Schindlers are certainly welcome to their views about the value of all life, and if they wish to adopt a "vitalist" approach-life at all or nearly any cost-then that is their prerogative to do so. But it is not their prerogative to impose that view on someone else, even if it is their daughter. And the crux of the problem with our current statutory approach to these decisions is that a surrogate essentially has the power to do just that. In Terri Schiavo's case, the Schindlers were not Terri's surrogate. But their strategy of attempting to remove Michael Schiavo and insert themselves in that role reveals the flaw of our current legal apparatus. They knew that who the surrogate was could make all the difference. Coupled with the presumption in favor of tube feeding, the appointment of Terri's parents as her surrogate would mean that she could have lived for several more decades for their sake, and only for their sake.

\section{CHANGING THE PRESUMPTION}

How can we avoid the intrusion of others' interests in the treatment decisions that are made for incompetent patients? In the case of most incompetent patients, this is indeed a very tall order. For a

175 Id.

176 Id.

177 Id. During the trial at which this testimony took place, the Schindlers, according to the Guardian's Ad Litem report, acknowledged that Terri was in a persistent vegetative state, although they would later raise challenges to that diagnosis. Id. 
minimally functioning patient whose spouse arrives daily to visit and interact, even in a minimal way with the patient, it would be very difficult to determine when the spouse, acting as surrogate, is considering the patient's interests or the spouse's own interests. But with individuals in a permanent vegetative state, the answers are clearer. As argued above, because such individuals have no present or future interest in living, they should be treated differently from other severely disabled individuals. The law should recognize that because of the unique situation of people in a permanent vegetative state, the surrogate's role in such cases is more limited than in the case of the terminally ill or severely disabled because the surrogate does not need to engage in any complex balancing of the burdens and benefits of continued feeding of the patient.

Because people in a permanent vegetative state receive no benefit from continued living, there should be a presumption that they be allowed to die. Otherwise, they are simply living for others and are treated essentially as an object rather than as a person. The exception that we should maintain is that we should continue to feed the person who is now in a permanent vegetative state if such would be according to her wishes. Thus, while the presumption would change in favor of discontinuing feeding, it could be rebutted by evidence of the person's desires. The surrogate's role in the case of people in a permanent vegetative state would then be to bring forward any evidence that the person would have wanted to continue to be fed. An equally important role would be to guard and protect the patient against invasions of her bodily integrity and medical privacy.

As described above, state law now generally provides that surrogates can decide to discontinue treatment only if they have clear and convincing evidence that such decisions would be a patient's preference or, absent evidence of patient preferences, that such decisions would be in the patient's best interest. In its stead, the law I propose would read that, at a certain time (such as a year) following diagnosis of a patient's permanent vegetative condition, ${ }^{178}$ all life-sustaining treatment (including nutrition and hydration) would be terminated unless the surrogate makes a decision in favor of continued treatment

${ }^{178}$ Since under current clinical criteria, a diagnosis for permanent vegetativeness is made after three months in a vegetative state for those suffering a nontraumatic injury and one year for those suffering a traumatic injury, judicial or quasijudicial review would not be required until at least one year and three months, in the case of nontraumatic injury, and two years, in the case of traumatic injury, after the patient had entered a condition of vegetativeness. Prior to required judicial review but after the diagnosis of permanent vegetativeness, a surrogate could withdraw tube feeding unless clearly contrary to the patient's preferences. 
on the basis of clear and convincing evidence that continued treatment would be the patient's preference. ${ }^{179}$ Gone would be the individualized best interests analysis out of recognition that patients in a permanent vegetative state uniformly have no present or future interest in living that they can experience. Only if the patient would have wished for continued feeding would it be permitted out of respect for the patient's autonomy. Under this proposed reform, surrogates would not be permitted to authorize the continued feeding of a vegetative patient to further their own or others' interests. The state's role in protecting the patient from being used as an instrument for others takes precedence over the state's interest in sustaining vegetative life.

The justification for this change in the presumption is that continued feeding of the vegetative patient, if not in accordance with the person's wishes, is driven only by the interests of others and not by the interests of the patient. Such forced use of the body of the person for others' interests does a wrong to that person even though she cannot experience such wrong. Norman Cantor gives us an example of such an invasion of the person by asking us to consider whether a photographer who snuck into a hospital room of a vegetative patient and took pictures of her, which he later published, would be invading her privacy. ${ }^{180}$ Most people would probably think that such an action would be invasive. ${ }^{181}$ That example seems almost quaint compared to the invasion of privacy that has occurred with Terri Schiavo. ${ }^{182}$

The wrong does not have to involve privacy concerns, however, and can simply occur through use of the person's body, as another example that Cantor provides reveals, that of organ harvesting. ${ }^{183} \mathrm{We}$ do not allow the harvesting of non-vital organs from patients in a permanent vegetative state even though they can continue living in their vegetative state without those organs. We do not, for example, harvest the corneas of those patients, even though they cannot use the corneas to see and others may be able to. The body of the patient in a

179 If a proposal such as this one were adopted, we would have to give further consideration to the appropriate burden of proof. Preponderance of the evidence could also be considered. In addition to choosing between a preponderance of the evidence standard or a clear and convincing standard, there are further questions as to what kind of evidence might be considered-for example, whether only statements of the patient should be considered, and if so, how specific they must be, or whether evidence of the patient's values and personalities can also carry weight.

${ }^{180}$ Cantor, supra note 85 , at 404.

181 Id.

182 Donors of $\$ 100$ or more to the Life Legal Defense Foundation (which helped pay for the Schindlers' legal fees) could receive a videotape of Terri Schiavo in her bed. Nohlgren \& Zucco, supra note 162, at $1 \mathrm{~A}$.

${ }^{183}$ Id. 
permanent vegetative state is not for others to mine, either for parts or images. But neither is it for people to sustain indefinitely in order to advance more abstract interests-such as the personal interest of parents in not losing a child, or the ideological interests of a physician in providing all available treatment.

\section{OBJECTIONS}

While my argument in favor of a presumption against feeding for a person in a permanent vegetative state is based upon the fact that there is no reason to continue to feed that has any relevance to that person, one might object that there are reasons unrelated to the person's benefit that can justify continued feeding. I consider such possible reasons below. The problem with each of them is that they in essence prove my point; reasons unrelated to the person's benefit are inherently suspect, and upon closer examination, are not justified out of respect for the person whose treatment is being considered.

The most charitable reasons for a presumption in favor of feeding in the absence of evidence of the patient's wishes are: (1) feeding is basic care, which we have a duty to provide for all people; (2) all human life is precious and should be sustained because of the sanctity of life; (3) most people would want to be fed even if they have become permanently unconscious (if that were true); (4) feeding people in a permanent vegetative state is necessary in order to ensure proper care and respect of other severely disabled human beings; (5) we should allow continued feeding out of concern for loved ones. ${ }^{184}$

\section{A. Objection: Feeding Is Basic Care}

The idea that withholding nutrition and hydration from a person is different from withholding other types of life-sustaining proceduresbecause it represents a lack of care and a form of abuse in hastening death-was central to the controversy surrounding Terri Schiavo. Supporters of the Schindlers repeatedly charged that Terri's husband and the courts were making decisions to "starve" her to death. ${ }^{185}$

184 Some might object that my proposal does not go far enough-that if the decision is made to discontinue tube feeding, which will certainly lead to death, then why not provide the patient with a lethal injection to hasten the process? This objection involves questions about euthanasia that go well beyond the situation of people in a permanent vegetative state, and applies equally to our current system that allows (but with much more difficulty) surrogates to withdraw tube feeding.

${ }_{185}$ See Bruce Hosking, Mom Makes Plea to Save Daughter; Congress Move Could Reinstate Feeding Tube for Terri Schiavo, TORONTO STAR, Mar. 20, 2005, at A02 (describing protestors symbolically attempting to bring food and water to Terri Schiavo outside her hospice); CNN News: Terri Schiavo, 41, Dies (CNN television 
When Terri's Law was passed in 2003, there were many references by supporters of the law to a "stay of execution" for Terri. ${ }^{186}$ When the Schindlers in early 2004 filed a petition urging that Terri be given swallowing tests and therapy, they invoked a Florida statute providing that it is a felony to withhold food from a disabled or vulnerable adult. ${ }^{187}$ In the spring of 2004 , a bill was introduced into the Florida legislature to adopt more stringent procedures for withdrawing nutrition and hydration from an incompetent patient as compared to the procedures applicable to the withdrawal of other life-sustaining treatments. ${ }^{188}$ The bill's title is a testament to the emotional nature of the question of feeding: the "Starvation and Dehydration of Persons with Disabilities Prevention Act." 189 In early 2005, with the third removal of Terri's feeding tube imminent, the Florida legislature again considered, but did not pass, legislation that would make withdrawal of tube feeding from people in a permanent vegetative state virtually impossible in the absence of a written living will. ${ }^{190}$

broadcast Mar. 31, 2005) (featuring video clip of Rep. Tom DeLay stating, "A young woman in Florida is being dehydrated and starved to death."); Nat'l Right to Life, Spurred by Schindler-Schiavo Case, Model State Law to Prevent Starvation and Dehydration Proposed, http:/www.nrlc.org/euthanasia/ModelBillAnnoucement.html [hereinafter NRLC MODEL STATE LAW] (last visited Sept. 30, 2005) (National Right to Life Committee's charge of starvation); Issues Surrounding Terri SchindlerSchiavo Are Disability Rights Issues, Say National Disability Organizations, Oct. 27, 2003, available at http://www.raggededgemagazine.com/schiavostatement.html (signed by twenty-three national disability rights groups and referring to Ms. Schiavo's "death by starvation").

${ }^{186}$ See, e.g., Adam Liptak, In Florida Right-to-Die Case, Legislation That Puts the Constitution at Issue, N.Y. TIMES, Oct. 23, 2003, at A20 ("It's beautifully badly drafted,' said Patrick $O$. Gudridge, a law professor at the University of Miami. . . . They wanted to use the word "stay," Professor Gudridge said of the [Florida] Legislature, 'because the analogy is to a stay of execution."').

${ }_{187}$ Petitioners' Response to Court's Request Regarding Guardian Ad Litem, In re Guardianship of Schiavo, No. 90-2908GD-003 (Fla. Cir. Ct. Jan. 5, 2004). See FLA. STAT. ANN. $\$ 825.102(3)$ (West 2000), which in certain circumstances makes neglect of an elderly or disabled adult a felony and defines neglect to include:

A caregiver's failure or omission to provide an elderly person or disabled adult with the care, supervision, and services necessary to maintain the elderly person's or disabled adult's physical and mental health, including, but not limited to, food, nutrition, clothing, shelter, supervision, medicine, and medical services that a prudent person would consider essential for the well-being of the elderly person or disabled adult.

188 S.B. 692 (Fla. 2004).

189 S.B. 692. This bill was modeled on an act proposed by the National Right to Life Committee. See NRLC MODEL STATE LAW, supra note 185.

${ }^{190}$ H.B. 0701 (Fla. 2005). The Florida Senate also considered a bill that took a different approach, prohibiting the removal of a feeding tube from an individual in a permanent vegetative state in the event of disagreement among individuals who could 
The Pope of the Roman Catholic Church also weighed in on the issue. In the spring of 2004, in the midst of publicity about Terri Schiavo's case, Pope John Paul II released a statement declaring that artificial nutrition and hydration were not like other medical treatments, but constituted "basic care." duty to provide tube feeding for patients like Terri. While not considered canon law, this statement of the Pope drew much attention. At the time, the Church's policy and the practice of Catholic hospitals in the United States had been to allow family members more discretion to withdraw artificial nutrition and hydration for patients in a permanent vegetative state. ${ }^{192}$ The Pope's statement called that policy into question.

These developments challenge what had appeared to be a legal and medical consensus that the provision of artificial nutrition and hydration was like other life-sustaining medical treatment which could, if unwanted, constitute intrusions of bodily integrity that are unacceptable under medical ethics, common law, and constitutional law principles. Since the 1980 s, courts have consistently (but not uniformly) held that artificial nutrition and hydration (feeding by tube)

have served as an individual's surrogate under the statutory hierarchy for surrogacy status. S. 0804Cl (Fla. 2005).

191 Pope John Paul II, Address to the Participants in the International Congress on "Life-Sustaining Treatments and Vegetative State: Scientific Advances and Ethical Dilemmas," available at http://www.vatican.va/holy_father/john_paul_ii/ speeches/2004/march/documents/hf_jp-ii_spe_20040320_congress-fiamc_en.html (Mar. 20, 2004). The Pope's address contained the following passages, among others, relating to the care owed to the person in a permanent vegetative state:

The sick person in a vegetative state, awaiting recovery or a natural end, still has the right to basic health care (nutrition, hydration, cleanliness, warmth, etc.), and to the prevention of complications related to his confinement to bed. He also has the right to appropriate rehabilitative care and to be monitored for clinical signs of eventual recovery.

I should like particularly to underline how the administration of water and food, even when provided by artificial means, always represents a natural means of preserving life, not a medical act. Its use, furthermore, should be considered, in principle, ordinary and proportionate, and as such morally obligatory, insofar as and until it is seen to have attained its proper finality, which in the present case consists in providing nourishment to the patient and alleviation of his suffering.

Id. See generally Leonard J. Nelson, III, Catholic Bioethics and the Case of Terri Schiavo, 35 CUMB. L. REv. 543, 567 (2005).

${ }_{192}$ This was permitted under the more general policy that artificial nutrition and hydration can be withdrawn from incompetent patients when continued treatment is burdensome to the patient or the patient's family. Nelson, III, supra note 191, at 571. 
should be understood in the same way as a ventilator, or dialysis, or other invasive medical procedures used to prolong life. ${ }^{193}$

What are we to make of this argument that feeding is basic care and should not be withdrawn? How strong an objection is this to a presumption in favor of discontinuing the feeding of a person in a permanent vegetative state?

The problem with this objection is its presumption that "basic care" means something that we all know and understand. Labeling something as "basic care" does not make it so, nor does it explain what the label is intended to mean.

In our particular instance, the instance of the person in a permanent vegetative state, we have to go beyond the label and question what might be meant. What is the impetus, motivation, ultimate goal of the provision of basic care?

While feeding can continue the life of a person in a permanent vegetative state, and can do so without physical burden, it does not necessarily constitute required care. For one, it is not "experienced" as care by the patient, who is unaware that she is being fed or that she has been fed. We might contrast this situation to that of a severely disabled, conscious patient who might experience care in the form of feeding by the social relationship created through feeding or by the physical pleasure of eating through the experience of taste or satiation. In that instance, the argument that feeding is basic care is more convincing, but it does not apply to our case.

Second, even if we might consider feeding to be basic care not because of the experience of feeding in and of itself, but because of the end it produces - continuation of life-there are difficulties with this conception of feeding as applied to the permanently vegetative patient as well. This argument of feeding as basic care would apply to the person in a coma, but not a person in a permanent vegetative state. We may well think that feeding is required for someone in a coma even though they cannot experience such feeding as care because for that person there may be some possibility of recovery. Feeding perpetuates the life of the comatose person with the possibility that life may once again be experienced. But in the case of the permanently vegetative patient, there is virtually no possibility of a life that will ever be experienced again.

193 See MEISEl \& CERMINARA, supra note 90, at $\$$ 6.03[G][4] (3rd ed. 2005) (reporting the "virtual unanimity among appellate courts permitting the foregoing of medically supplied nutrition and hydration"). See also In re Browning, 568 So.2d 4, 11-12 (Fla. 1990) ("Courts overwhelmingly have held that a person may refuse or remove artificial life-support, whether supplying oxygen by a mechanical respirator or supplying food and water through a feeding tube."). 
Neither the social act of providing food as a form of care nor the outcome produced by food (continued life) is experienced by the person in a permanent vegetative state. Lack of the ability to experience is not enough, however, to dismiss the idea that a certain degree of care is owed to such patients. Some of the motivation here is understandable. We would want the vegetative patient to be kept clean and presentable and free of bed sores to the extent possible even though she would not know the difference, even though she would not benefit in terms of any experience. How is feeding different from these common and expected acts of human decency?

For people in a permanent vegetative state, tube feeding is less like these acts of common decency and more like a ventilator because the provision of nutrition and hydration through a PEG tube is not about respecting the body's integrity or its appearance but is solely about sustaining life. In fact, the surgically inserted feeding tube is an invasion of bodily integrity and the nutrition and hydration supplied through that tube commonly causes a bloated appearance of the body. ${ }^{194}$

Feeding tubes, ventilators, and dialysis machines for people in a permanent vegetative state sustain their lives, but because they have no interest in continuing to live those lives, removal of these treatments is appropriate. When we remove a ventilator from a patient, we understand that the patient may die, but we do not say that we are causing her to suffocate to death; when we remove dialysis we do not say we are poisoning the patient. Statements that Terri Schiavo was starved to death are likewise inflammatory, suggesting a lack of care that is not true.

The care that is owed here (to the body and its appearance) is like that owed to everyone-from a temporarily unconscious person to a dead person. Those who have temporarily lost consciousness or who have died also cannot experience how their body is treated, but we treat them with respect and care-and not just respect for people in general, but respect for these particular people or, in the case of the dead, the person they were.

194 See CoLBY, supra note 97, at 84, 384 (describing the appearance of permanently vegetative patient Nancy Cruzan during the provision of artificial nutrition and hydration and after its removal). 


\section{B. Objection: All Human Life Is Precious and Should Be Sustained Because of the Sanctity of Life}

This, the "vitalist" position, is concerned with valuing and sustaining human life of any quality and kind. ${ }^{195}$ It may extend to embryos and fetuses as well as to patients in a permanent vegetative state. ${ }^{196}$ The vitalist argument was voiced repeatedly and loudly in the controversy over Terri Schiavo. Some of the strongest supporters of the Schindlers were right-to-life groups who have traditionally been more concerned with protecting nascent human life than protecting patients in a permanent vegetative state. ${ }^{197}$

A pure vitalist approach would not allow the discontinuation of life support mechanisms even where such treatments caused burdens to the patient, such as pain or discomfort, and even where such treatments were specifically rejected by the patient. ${ }^{198}$ No state has adopted such a strict position. ${ }^{199}$

A more limited vitalist position has been determined to be constitutionally permissible. The Supreme Court, in the Cruzan case in 1990 , recognized that states may assert an unqualified interest in life that permits them to continue life-sustaining treatment for incompetent patients in the absence of clear and convincing evidence that the patient expressly directed otherwise prior to losing competency. ${ }^{200}$ According to the Court, if an error of judgment might occur in these life or death decisions, the state is entirely justified in erring on the side of life. ${ }^{201}$

While the Supreme Court has given considerable latitude to states in asserting an interest in life and therefore limiting the right of incompetent individuals to have their life-sustaining treatment withdrawn, the states have also been free to adopt more permissive stan-

195 See Boozang, supra note 143. For a recent, thorough critique of the vitalist position, see Alicia R. Ouellette, When Vitalism is Dead Wrong: The Discrimination Against and Torture of Incompetent Patients by Compulsory Life-Sustaining Treatment, 79 IND. L.J. 1, 10 (2004).

196 Robertson, supra note 100, at 121 (describing both the Schiavo controversy and the embryonic stem cell debate as "involv[ing] a clash between strongly held vitalist views and a more pragmatic approach to questions of human dignity").

197 See Nohlgren \& Zucco, supra note 162, at $1 \mathrm{~A}$.

198 See Boozang, supra note 143 at 567 ("the sanctity-of-life principle, or vitalism, rests on the notion that life is an end in itself').

199 See MeISEL \& CERMINARA, supra note 90, at $§ 1.07$ [B].

200 Cruzan v. Dir., Mo. Dep't of Health, 497 U.S. 261 (1990) (upholding Missouri's law requiring clear and convincing evidence of expressed wishes of woman in persistent vegetative state before allowing withdrawal of nutrition and hydration).

${ }^{201}$ Id. at 283. 
dards. Most states have in fact done $\mathbf{s o}^{202}$ In addition to allowing surrogates to make a substituted judgment for the patient on the basis of evidence weaker than the patient's previously expressed preferences, a number of states also allow the withdrawing of life-sustaining treatment on the basis of the patient's best interests. ${ }^{203}$ Thus, most states, including Florida, do not adopt what might be considered a strong vitalist approach, but do assert an interest in continued life by a presumption against discontinuation of life-sustaining treatment. ${ }^{204}$

Even the more moderate vitalist might well object to my proposal to change this presumption so that continued feeding of the person in a permanent vegetative state is disfavored. The argument might be stated as follows: because human life of all sorts is valuable for its own sake, as an end in itself, then it should be sustained unless there is clear and convincing evidence that the individual would not wish it, or it is burdensome to the patient. In other words, the existing law with its presumption in favor of continued tube feeding and other medical treatment has it just right. It strikes an appropriate balance between the rights of the patient to autonomous decision-making, the interests of the patient in avoiding pain and suffering, and the state's interest in sustaining life. Why meddle with it?

202 See MeISEl \& CERMinaRA, supra note 90, at $\S 2.03$ [A][1] (noting that while some other states also require the use of a clear and convincing evidence standard with respect to honoring the actual or probable wishes of the patient, only Missouri and New York have required clear and convincing evidence that the patient herself authorized treatment withdrawal).

${ }^{203}$ See MEISEL \& CERMINARA, supra note 90, at $\$ 4.07[\mathrm{~B}]$ (pointing out that while some courts accept the best interests standard, few have actually applied it). A few states have maintained a strict, though not pure, vitalist position by requiring advance written directives before permitting the discontinuation of life-sustaining treatment, thus completely denying treatment withdrawal for individuals who have never been competent. New York has for years had one of the strictest positions in this regard and the recent case of Sheila Pouliot has forced a reconsideration of its merits. In that case a mentally retarded, terminally ill individual was forced to undergo life-sustaining treatments rejected by her surrogate. The treatments prolonged her life by only a few weeks but caused considerable pain and bodily degradation. Recent legislation, enacted in part in response to a lawsuit brought by Pouliot's guardian, has modified New York's law to allow more flexibility in withdrawal of treatment decisions. See Ouellette, supra note 195, at 2-3. It is difficult to predict, however, whether on the whole the law is developing toward less or more of a vitalist position. While New York's recent legislative change suggests a growing awareness that the costs (especially in terms of pain and suffering) of sustaining all life must be considered, the acts of the governor and legislature in Florida in respect to Terri Schiavo, and the legislature's consideration of legislation to further restrict discontinuation of nutrition and hydration suggest the openness of at least some state legislators to a more vitalist position.

${ }^{204}$ See discussion supra Part III.B. 
The reason to revise current state law to provide for a presumption against feeding in a permanent vegetative state, and to reject even the limited vitalist position of most state law (including Florida), is that such a revision would in fact exhibit more respect for the individual human life than a presumption in favor of continued living would. Why is this so? Because the heart of the principle to respect human life is to respect the individual human life, not the process of life itself. In other words, it is what has come together to make a living person that is to be respected, rather than individual living cells. Right-to-life advocates, for example, who object to research on human embryos, do not generally object to research on mere cells, even if the cells are living and contain a full set of human DNA. To such advocates, research on adult stem cells is permissible, but research on embryonic stem cells is not, since the latter involves the destruction of a human embryo, which they believe is a person. ${ }^{205}$

It is the individual human life that is endowed with the qualities that command respect as a person. For the religious, this may be connected to the creation of an individual human soul. For those who apply such principles to embryos, the combining of the genetic material of the gametes creates the individual human life. But it is not life processes themselves that are valued for their own sake. As an earlier encyclical letter of Pope John Paul II states,

[F]rom the time that the ovum is fertilized, a life is begun which is neither that of the father nor the mother; it is rather the life of a new human being with his own growth. It would never be made human if it were not human already. This has always been clear, and ... modern genetic science offers clear confirmation. It has demonstrated that from the first instance there is established the program of what this living being will

${ }^{205}$ See, e.g., the following statement made by The Coalition of Americans for Research Ethics:

Stem cell research promises great good and is a worthy scientific priority as long as we pursue it ethically. Obtaining stem cells from people without seriously harming people in the process can be ethical. However, obtaining stem cells from human embryos cannot be ethical because it necessarily involves destroying those embryos.

Coal. of Ams. for Research Ethics, On Human Embryos and Stem Cell Research: The Founding Statement of Do No Harm: The Coalition of Americans for Research Ethics (Jul. 1, 1999), http://www.stemcellresearch.org/statement/index.html. The website of The Coalition of Americans for Research Ethics is referenced in the website of the National Right to Life Committee. Nat'l Right to Life, Killing Human Embryos: (Human Cloning and Related Issues), http://www.nrlc.org/killing_embryos/index. html (last visited May 15, 2006). 
be: a person, this individual person with his characteristic aspects already well determined. ${ }^{206}$

In explaining why prenatal human life must be respected, the Pope's encyclical letter emphasizes the individuality of every human being with its own genetic make-up. The text's focus is not on the presence of mere primitive human biological functions, such as respiration, but on unique human individuality.

So how do we best respect the individual person who has entered a permanent vegetative state? Merely acknowledging that her body continues to function and insisting that it function perpetually is not the answer. The individual who was Terri Schiavo had been stripped by medical trauma of all qualities that might matter to her individuality - that might make her a person with individual qualities of any sort-excepting relationships with others. But these relationships with others were no longer her relationships, because she could not experience them. The relationships, with family and friends, only benefited others.

Rather than err on the side of life, which can never be experienced, the law should err on the side of not allowing one individual to be used for another - it should err on the side of the inviolability of the individual. A presumption in favor of discontinuing artificial nutrition and hydration actually shows more respect for the individual human life than a presumption in favor of continued living, because it acknowledges that the individual qualities of the person have been lost. As has already been shown, a presumption in favor of continued living allows the individual in a permanent vegetative state to be treated as a means to others' ends, rather than an end in herself.

In this regard it is important to emphasize, again, that the changes to the law that I propose do not affect individuals who are capable of experiencing life, even if in a limited fashion. Such cases of individuals with severe disabilities are distinctly different from the case of the person in a permanent vegetative state. There, as with assessing benefits as against burdens of living, one would have to engage in a more complex assessment of whether it is best to err on the side of life (which can be experienced) or on the side of the inviolability of the individual. Because life cannot be experienced by people in a permanent vegetative state, they have no interest in continuing it. At the same time, our duties to treat them as persons deserving of respect

206 Pope John Paul II, Evangelium Vitae (The Gospel of Life) (1995) (internal quotations and citations omitted). 
continues. That respect means that we should err on the side of protecting them from being used by others.

\section{Objection: Most People Would Want to Be Fed in a Permanent Vegetative State}

Some might argue that a presumption in favor of discontinuing feeding presumes in essence that most people would not want to be fed in these circumstances. That is not the basis for my argument against feeding the permanently vegetative. ${ }^{207}$ Making decisions about whether someone should live or die on the basis of how a majority of people would feel about living in this or that condition would deny the individual nature of such decisions. There would be no obvious reason to confine such basis for decision-making to those in a permanent vegetative state, and the possibility of uninformed bias against life in certain disabled states would be great. The basis for my argument against feeding the permanently vegetative is not a majority-based "substituted judgment" for the person whose desires are unknown; it is instead based upon the lack of any benefit to continued living combined with the vulnerability of being used as an instrument to others' ends.

That said, however, what if there were evidence that most people would in fact affirmatively want to be fed in a state of permanent vegetation? Such evidence would call into question the accuracy of my evaluation that such people have no interests in present or future life. It would suggest that perhaps there are interests in living that I have overlooked but that most people feel exist-and that we need to dig deeper to discover what those interests might be.

Not surprisingly, however, most people, when asked whether they would want to be kept alive by a feeding tube if they became permanently unconscious, answer "no." In fact, they answer no in overwhelming percentages. Justice Brennan's dissent in the 1990 Cruzan case cites a Colorado University Graduate School of Public Affairs' study in which 85 percent of those people questioned answered that they would not want a feeding tube if they became permanently unconscious. ${ }^{208}$ Surveys taken during the unfolding of the Schiavo controversy in 2005 were consistent with this earlier survey data. They

${ }^{207}$ But see Cantor, supra note 90, at 1197 (arguing that "the preference of a previously competent patient--in the absence of explicit instructions or special personal values concerning death and dying--should be grounded on default principles drawn from most people's vision of intolerable indignity").

${ }^{208}$ Cruzan v. Dir., Mo. Dep't of Health, 497 U.S. 261, 312 n.11 (1990) (Brennan, J., dissenting). 
also revealed that a high percentage of Americans ( 78 percent to 82 percent) would not want to be kept alive if they were in a permanent vegetative state. $^{209}$

D. Objection: Feeding the Person in a Permanent Vegetative State Is Necessary in Order to Ensure Proper Care and Respect of Other Severely Disabled Human Beings

The concern of this objection is somewhat of a "slippery slope" argument. If the law presumes that we should not feed individuals in a permanent vegetative state, then might the law likewise embrace presumptions against life for other individuals in severely disabled conditions? In important ways, a concern to protect other severely disabled individuals rather than those in a permanent vegetative state or, more particularly, Terri Schiavo herself, seemed to be the impetus behind a number of disability rights groups' support of the Schindlers' cause to keep Terri Schiavo alive. For example, twenty-one national disability rights organizations signed a letter in October of 2003 in support of the continued feeding of Terri Schiavo that spoke as much or more about people with disabilities in general than it did about Terri, comparing her situation with that of persons with Down syndrome, autism, and ALS. ${ }^{210}$ The letter stated that the "life-and-death issues surrounding Terri Schindler-Schiavo are first and foremost disability rights issues" and "Terri Schindler-Schiavo's fate is entwined with all disabled people who rely on surrogates."211

It is certainly right for advocates for people with disabilities to be concerned about the law of end-of-life decision-making and how it may reflect prejudice and intolerance of disability and difference. But the situation of the person in a permanent vegetative state must be considered on its own terms, rather than as one sort of severe disability. As explained above, there is a sharp difference between no cognition and some cognition, for the person with some cognition may experience some benefit to continued living. Failing to treat people in a permanent vegetative state consonant with their condition in order to protect other severely disabled people is but another example of instrumentality. Keeping Terri Schiavo alive for the benefit of other

${ }^{209}$ See Robert J. Blendon et al., The American Public and the Terri Schiavo Case, 165 ARchives InTERNAL MED. 2580, 2583 (2005) (citations omitted). When asked specifically about disconnecting a feeding tube in such condition, the numbers dropped to between 61 percent and 69 percent. Id.

${ }^{210}$ ADA Watch et al., Statement, Terri Schindler-Schiavo and Disability Rights, THEARCLINK.ORG (Oct. 27, 2003), available at http://www.thearclink.org/ news/article.asp?ID $=623$.

${ }^{211} I d$. 
people with severe disabilities is no more morally acceptable than keeping her alive for her parents or for doctors or for the Governor of Florida. It is especially disconcerting to witness groups who purport to stand up for the vulnerable in our society to use one of those vulnerable people for their cause.

Furthermore, failing to treat the person in a permanent vegetative state differently, as their different circumstances warrant, might actually do a disservice to other severely disabled human beings. ${ }^{212}$ The distinction between no capacity to experience life and some capacity should be preserved and emphasized by those who believe that they are doing good for people with disabilities by protecting them from the withdrawal of life-sustaining treatment. For people with severe disabilities who are not permanently unconscious, there are benefits to living that must be considered, and disability rights groups should emphasize those interests. Because of those interests, perhaps we should as a society err on the side of life for those individuals with severe disabilities, but these considerations ring hollow for the person in a permanent vegetative state.

\section{E. Objection: We Should Allow Continued Feeding Out of Concern for Loved Ones}

Under my proposal, feeding would not be continued after a certain time period unless the patient would have wanted it. Family members would not be allowed to continue the lives of such individuals because of their own needs or desires. If Mary Schindler had been designated by statute to be Terri's surrogate, she would not under my proposal have been permitted to keep Terri alive beyond the point at which judicial or quasi-judicial review would automatically take place unless she could prove Terri would have wanted continued feeding. An order would be issued to discontinue feeding. This may seem rather harsh. Should we not value family relationships? Should we not be sensitive to the needs of those who are living and can experience the consequences of the decision to discontinue feeding of their loved ones?

We should value family relationships and we should exhibit such sensitivity, but there simply have to be limits unless we are going to sanction long-term instrumental use of the permanently vegetative. We should accommodate family interests, but not to the extent of allowing those interests to trump respect for the patient. ${ }^{213}$ Such ac-

212 See generally Lois Shepherd, Terri Schiavo and the Disability Rights Community: A Cause for Concern, 2006 U. CHI. LEGAL F. (forthcoming 2006).

${ }_{213}$ There may be instances in which the surrogate could show that the patient wanted the surrogate to do what was in the interests of family members, and that what 
commodation may take the form of emotional support, the sharing of information about the patient's condition from professionals to surrogate and vice versa, and the acquiescence in some delay or additional period of observation or tests. Some delay, in fact, is built into the process I propose. Feeding tubes can be removed upon a diagnosis of a permanent vegetative state confirmed by at least two doctors, but if they are not removed upon the surrogate's instigation, their continued use will not be reviewed for a year or perhaps two. This additional time would allow a family member some opportunity to understand and perhaps accept the condition of the patient.

The well known case of Baby $K$ suggests the need to exercise some caution here. ${ }^{214}$ In that case, the mother of an infant born with anencephaly (a condition in which the child's upper brain is undeveloped and which is generally understood as involving no present or future consciousness), insisted that her daughter be given respiratory support to sustain her life. ${ }^{215} \mathrm{~A}$ court upheld her request against doctors' insistence that such treatment was futile and therefore in conflict with medical ethics. ${ }^{216}$ In many ways the case is not applicable to the primary questions raised by this article-it involved questions about medical futility, a concept that has waned in succeeding years, and federal regulations requiring emergency care-but it still provides a compelling example of a mother's dedication to keep her child alive. A strict application of my proposal would require withdrawing feeding tubes from such children after a certain period of time, such as two years, because there would not be any sense in considering evidence of the patient's desires regarding continued treatment. In other words, only the patient's experiential interests would come into play, since she would not have any self-determining preferences.

Baby $\mathrm{K}$ is a hard case, as would be the cases of other children who entered a permanent vegetative state after trauma or who never possessed consciousness to begin with. After an adequate period of time, however (and we might want to consider a different time period for minor children), it seems that the overriding principle of disallowing the instrumental use of the person should be honored and the feeding tubes and other life support removed.

In some important ways, changing the presumption from continuing tube feeding to discontinuing it may actually serve families who

is in the interests of family members is to continue tube feeding. In such a case, if the evidence is sufficient that this is what the patient would want, feeding could be continued.
214 In re Baby K, 16 F.3d 590 (4th Cir. 1994).
215
Id. at 592-93.
Id. at 597. 
are faced with these decisions. The current presumption in favor of feeding likely carries significant weight as a statement of our society's moral judgment about what should be done. Rather than request that feeding be withdrawn, even if they believe it is the right thing to do, surrogates may be discouraged from doing so because it seems morally suspect when the presumption is to continue feeding. The controversy over Terri Schiavo and the vehemence of protesters regarding removal of her feeding tube may further cause family members to experience confusion about what their ethical and legal obligations are.

\section{CONCLUSION}

When those who fight for the continued feeding of people like Terri Schiavo describe the withdrawal of nutrition and hydration as "cruel starvation," the inclination of those who believe feeding should be discontinued has been to deflate the emotive power of such claims: artificial nutrition and hydration is medical treatment, we say; or the person in a permanent vegetative state will not experience starvation, so it cannot be cruel; or this situation is a far cry from the malnourishment of children through neglect. Likewise, when proponents of continued feeding tubes for people in a permanent vegetative state make claims about the sanctity of all human life, we on the other side have attempted to dismiss such statements as being religiously based and narrow, rather than appropriately secular and universal. Or we have pointed to the broader agenda of those making the sanctity of life claim and charge that what is really behind this rhetoric is an interest in protecting fetuses and embryos. If the proponents raise concerns that withdrawing tube feeding from people in a permanent vegetative state sets a precedent that will disvalue, harm, and ultimately kill other people with disabilities, those who believe tube feeding should be discontinued have turned to medical definitions to distinguish these two groups of people, and again, to diffuse the passionate rhetoric with dispassionate argument.

But those who disagree with laws that promote or even require indefinite tube feeding of patients in a permanent vegetative state are also justified in bringing passion to this debate. Continued feeding, when pursued in the absence of knowledge that it is what the patient would want, violates an ethical principle as important as the provision of basic care, or the protection of life, or the equal treatment of persons with disabilities. It violates the principle that we should treat persons as "ends in themselves" and not as a means to others' ends; that we should respect them as persons rather than treat them as mere objects. In fact, this principle is much more centrally implicated in the 
continued tube feeding of people in a permanent vegetative state than the principles asserted by those who advocate continued feeding and justifies changing the presumption from perpetual tube feeding to its discontinuation. 
